\title{
EL VASO DEL «CICLO DE LA VIDA» DE VALENCIA: UNA REFLEXIÓN SOBRE LA IMAGEN METAMÓRFICA EN ÉPOCA IBEROHELENÍSTICA ${ }^{1}$
}

\author{
POR \\ RICARDO OLMOS \\ Instituto de Historia, CSIC \\ Con anexo de \\ M. ${ }^{a}$ LUISA SERRANO MARCOS
}

PALABRAS CLAVE: Mitología ibérica. Fundación de ciudades. Análisis iconográfico. Cerámica ibérica. Oppidum de Valentia. Siglo I a.C.

KEY WORDS: Iberian mythology. Foundations of towns. Iconographic analysis. Iberian pottery. Oppidum of Valentia. $1^{\text {st }}$ century BC.

\section{RESUMEN}

Se interpreta un nuevo vaso cerámico ibérico de época sertoriana aparecido en la plaza de Cisneros de Valencia: en el friso de animales que decora ambas caras se representaría un prodigium, alusivo a la historia del oppidum y los agri de Valentia, tal vez una imagen mítica de fundación. Este vaso sirve para interpretar la nueva iconografía de las metamorfosis y nos asoma a la apropiación metafórica y política de la naturaleza por parte del poder en época iberohelenística.

\section{SUMMARY}

An interpretation is given of a new Iberian ceramic vase from the Sertorian period, discovered in the Plaza de Cisneros in Valencia. The frieze of animals decorating both sides shows a prodigium, alluding to the history of the oppidum and the agri of Valentia, perhaps an original thematic image. This vase allows an interpretation of the new iconography of metamorphosis and shows us the metaphorical and political use of nature by the powers in the Iberian Hellenistic period.

En nuestro discurso sobre la representación de la naturaleza y del poder en época iberohelenística nos va a guiar un vaso ibérico, hallado recientemente en las excavaciones del casco antiguo de la ciudad de Valencia que coordina Albert Ribera, del Servicio de Investigación de Arqueología Municipal de Va-

1 Trabajo realizado dentro del proyecto de investigación: «Introducción a un Léxico de imagen prerromana en la Península Ibérica» (PB-97-1124), patrocinado por la DGICYT.

Agradezco a los Dres. Domingo Plácido, Isabel Izquierdo y Leonard Curchin una atenta lectura de mi manuscrito y sus valiosas observaciones. Algunas de sus sugerencias se han incorporado en el texto definitivo. Soy deudor asimismo de comentarios diversos de los colegas de la Universidad de Valencia, en cuyas aulas se acogió una discusión de esta pieza. Un seminario en el Instituto de Historia del CSIC ha permitido introducir también matices y correcciones significativas, con observaciones pertinentes de las Dras. Teresa Chapa y María Paz García-Bellido. lencia, a quien agradezco la posibilidad de estudiar y presentar este material ${ }^{2}$. Mi texto se complementa con un trabajo de María Luisa Serrano, directora de la excavación de donde procede el vaso, la Plaza de Cisneros. La documentación arqueológica del yacimiento que ella presenta, con un nivel de arrasamiento o destrucción de esta zona de la Valentia antigua motivado por la guerra civil que enfrenta a los partidarios de Sertorio con Pompeyo, arropa en su contexto e ilumina mis propuestas. El ejército de Pompeyo destruye la ciudad de Valentia, seguidora de Sertorio, en el año 75 a. de C. ${ }^{3}$. La Plaza de Cisneros se sitúa en la proximidad de lo que fue el antiguo puerto fluvial romano.

Junto al variado material helenístico de procedencia itálica y local hallado en viviendas y almacenes, que esta autora aquí describe, destacan especialmente dos grandes vasos de cerámica ibérica de perfil troncocónico, uno de ellos con la característica articulación en dos zonas en torno a las asas, distribución en metopas y con la conocida decoración geométrica - círculos colgantes-y tallos vegetales, donde lo geométrico y lo vegetal se confunden ${ }^{4}$.

El segundo vaso, que hoy nos ocupa, se decora con una secuencia de animales que llenan las caras A y B del friso correspondiente al espacio de las asas (figs. 1-4). Los elementos vegetales, profusos en la anterior tradición ibérica, tan cargados allí de significados (Elche, Liria, valle del Ebro...), tienen

2 Cf. María Luisa Serrano, «Excavaciones en Valencia», Revista de Arqueología n. ${ }^{\circ} 221$, Septiembre de 1999, pp. 2635. María Luisa Serrano y Remedios Martí, El vaso de «El ciclo de la Vida» (estudio preliminar), en: L'Arqueologia fa ciutat: les excavacions de la Plaça de Cisneros, Ajuntament de Valencia, Valencia, e.p.

3 Sobre este aspecto de la Valencia sertoriana desde los hallazgos de la antigua Almoina, cf. Albert Ribera i Lacomba (con análisis antropológico de Matías Calvo Gálvez), La primera evidencia arqueológica de la destrucción de Valentia por Pompeyo, Journal of Roman Archaeology, 8, 1995, pp. 19-40. Cf. el catálogo de la exposición, L'Almoina: de la fundació de València als orígens del cristianisme (textos de Carmen Martín, Albert Ribera y Miquel Roselló), Valencia, 1999

${ }^{4}$ M. ${ }^{a}$ L. Serrano, 1999, cit. (n. 2), p. 27. 


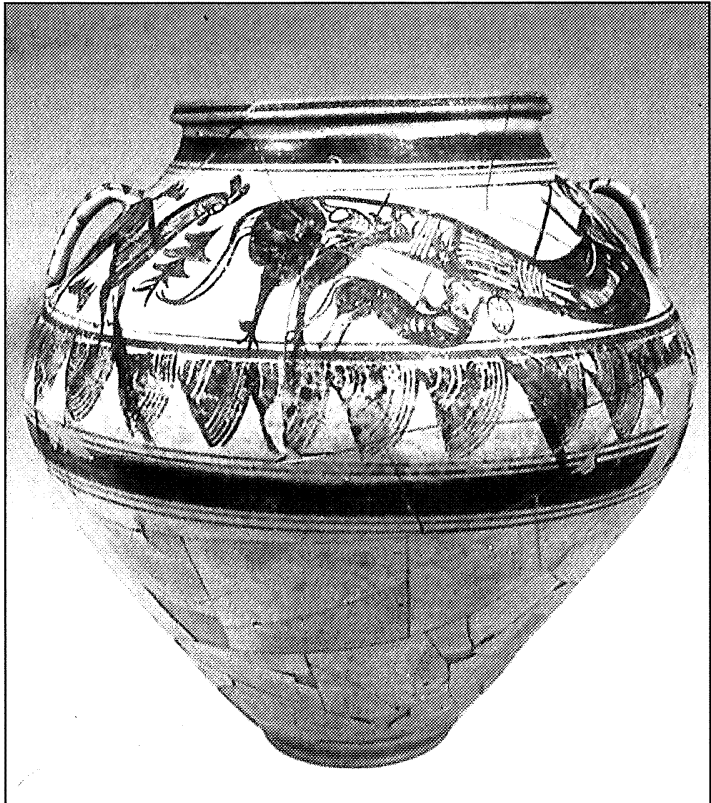

Fig. 1.- Vaso llamado del «Ciclo de la Vida», hallado en la Plaza de Cisneros de Valencia. S.I.A.M. Ayuntamiento de Valencia. Foto cortesía de María Luisa Ramos.

aquí presencia esporádica ${ }^{5}$. Interesa el linaje animal, la gens animantum, no las plantas. La escena se construye sobre una gran franja alargada formando una teoría o secuencia de animales que se mueven precipitadamente hacia la derecha (fig. 2). Les precede un equino, probablemente una yegua en actitud de carrera, con exageradas y numerosas mamas bajo el vientre. Sigue un ave, un gallo, bajo el arco de la cola equina. Cierra el grupo un enorme lobo o «carnassier», con las fauces abiertas y larga lengua. No resta espacio alguno entre los animales. Éstos se agrupan, son contiguos unos con otros.

Como es habitual en otras representaciones de la cerámica ibérica, especialmente del área de Elche, el cuerpo de ambos cuadrúpedos se articula en zonas: el cuello y su pelambre; el cilindro del vientre y sus costillas; las entrañas de la parte posterior, un círculo con partículas en movimiento de vida generadora, etc. ${ }^{6}$. Se ofrece, en gran medida, una geo-

5 Cf. infra, nota 14. Es difícil encuadrar en alguno de los talleres conocidos ibéricos este vaso. Se aparta notoriamente de Liria, de fecha anterior. No encaja tampoco con la producción de La Alcudia de Elche, con la que veremos comparte algún rasgo aislado. Hay también puntos de contacto, puntuales pero significativos, con la cerámica del Valle del Ebro (Azaila), como veremos. Por ejemplo, en la asunción de algún elemento iconográfico importante: el gallo; o el óvalo que decora la parte posterior del cuerpo de los cuadrúpedos. Cf. notas 6 y 9 . Pero no es hoy nuestra intención establecer en este trabajo un estudio estilístico de la pieza.

${ }^{6}$ Este círculo que expresa el interior fecundo se representa con frecuencia en la parte posterior de aves en la cerámica

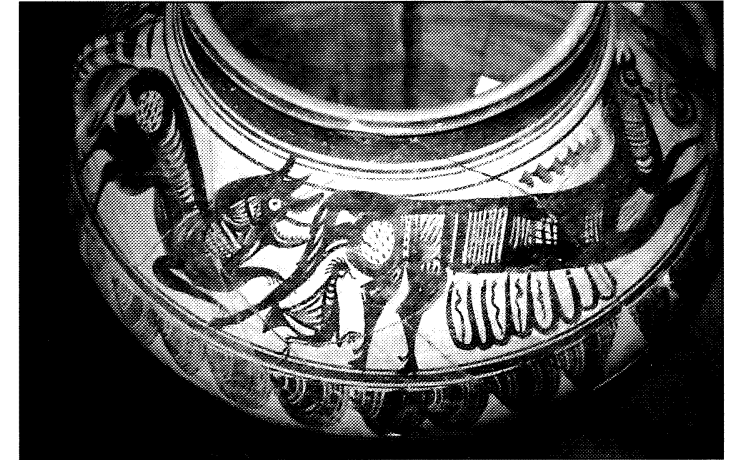

Fig. 2.-Friso de animales corriendo: yegua, gallo, «carnassier». Detalle del reverso de la fig. 1. S.I.A.M. Ayuntamiento de Valencia. Foto cortesía de María Luisa Ramos.

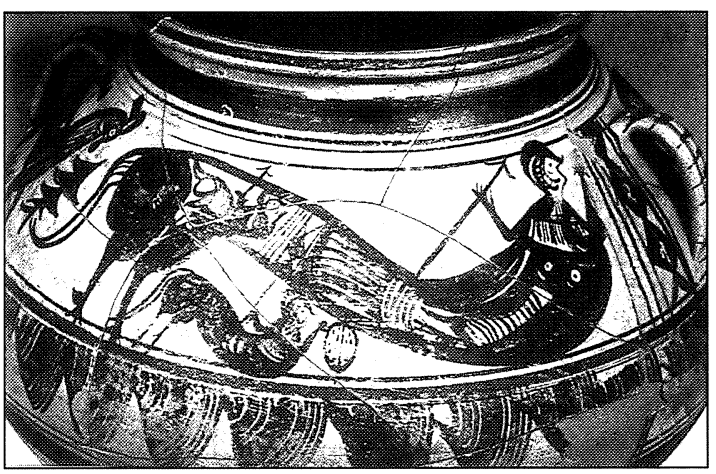

Fig. 3.-Escena mítica: monstruo engendrando seres míticos armados con «jabalina». Detalle del anverso del vaso llamado del «Ciclo de la Vida», Valencia. S.I.A.M. Ayuntamiento

de Valencia. Foto cortesía de María Luisa Ramos.

metrización del cuerpo del animal, que el pintor marca, de forma analítica, con diversas zonas que cubre con motivos ornamentales o descriptivos. Cada elemento del cuerpo es significativo, vital y autónomo.

En la otra cara del vaso, que podemos llamar principal, el esquema se repite y aquí podemos conocer mejor el proceso compositivo. El pintor ha cubierto la parte derecha del friso con una alargada figura monstruosa y ha llenado el espacio restante con un cuadrúpedo retraído, parado en seco (fig. 3). Éste se amolda claramente al friso sin cubrir por el ser mítico principal. Al contrario de lo que ocurría en la cara anterior, no hay contigüidad entre los dos seres. Les separa un arbusto que veremos cargado de intención ${ }^{7}$. Los rasgos de este segundo animal no respon-

del valle del Ebro, concretamente en la coetánea cerámica de Azaila, con la que comparte nuestro vaso este rasgo. Cf., ex. gratia, J. Cabré, Cerámica de Azaila. Corpus Vasorum Hispanorum, Madrid, 1944, p. 69 ss., figs. 55-58. Cf. infra, nota 21.

${ }^{7}$ Para el elemento vegetal como posible alusión paisajística entre el monstruo y el animal que le sigue, cf. infra, nota 14 . 


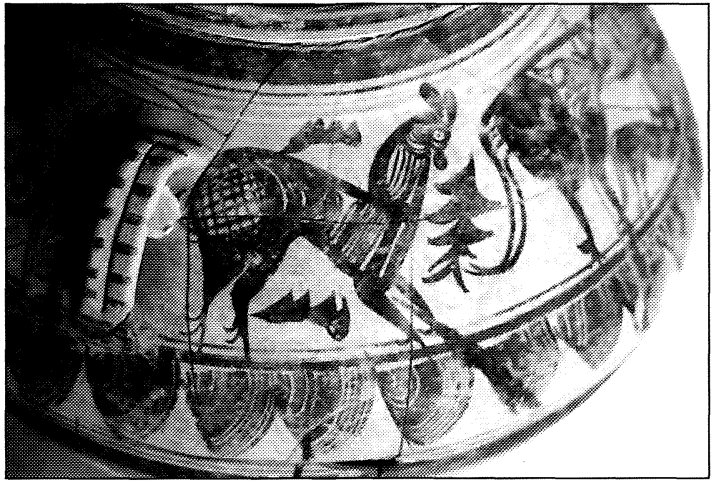

Fig. 4.-Cuadrúpedo (¿cierva?). Detalle de la cara con la escena mítica del vaso llamado del «Ciclo de la Vida», Valencia. S.I.A.M. Ayuntamiento de Valencia. Foto tomada du-

rante el proceso de restauración, cortesía del S.I.A.M.

den tampoco a una especie estrictamente real: oscila entre un caballo o un ciervo, o - más probablemente- una cierva, entre arbustos (fig. 4). Y, atención: de la secuencia de animales que llega corriendo desde la izquierda, es el único que se describe en el momento de pararse. Acaba de llegar hacia donde corría.

No hay intencionalidad clara de representar animales del universo cotidiano como, al contrario, vemos en la mayoría de los vasos de San Miguel de Liria. En uno de los grandes vasos de bebida aristocráticos, al modo de cratera, vemos al perro rascándose, al toro embistiendo o al caballo encabritado ${ }^{8}$ (figs. 5-7). Se cuentan diferentes rituales de iniciación de adolescentes en pruebas de doma (caso del

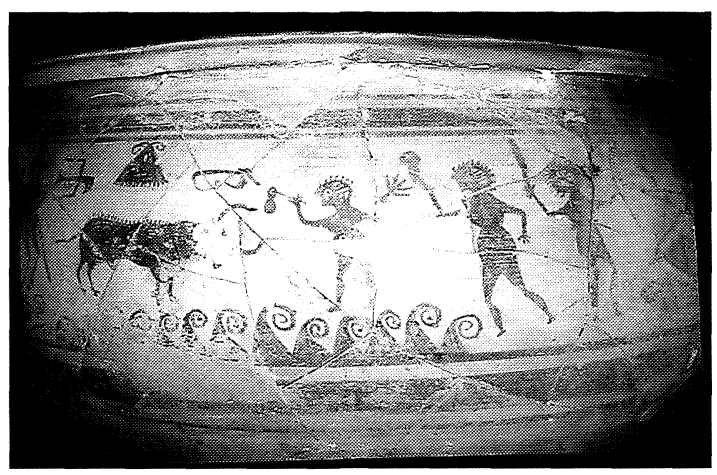

Fig. 5.-Gran vaso abierto, tipo «lebeta», del poblado de San Miguel de Liria (Valencia). Escena de incitación de un toro. A la derecha, combate singular entre dos guerreros. Museo de Prehistoria de Valencia. Foto cortesía del S.I.P., Valencia.

8 Helena Bonet, El Tossal de Sant Miquel de Llíria: la antigua Edeta y su territorio. S.I.P., Diputación de Valencia. Valencia, 1995 , p. 135 , fig. 61 , n. ${ }^{\circ} 11$; Ricardo Olmos, «Naturaleza y poder en la imagen ibérica», en: Carmen Aranegui, (ed.), Los Iberos, príncipes de Occidente. Actas del Congreso Internacional (Barcelona 12-14 marzo de 1998), Fundación «La Caixa», Barcelona, 1998, pp. 155-156, fig. 11.

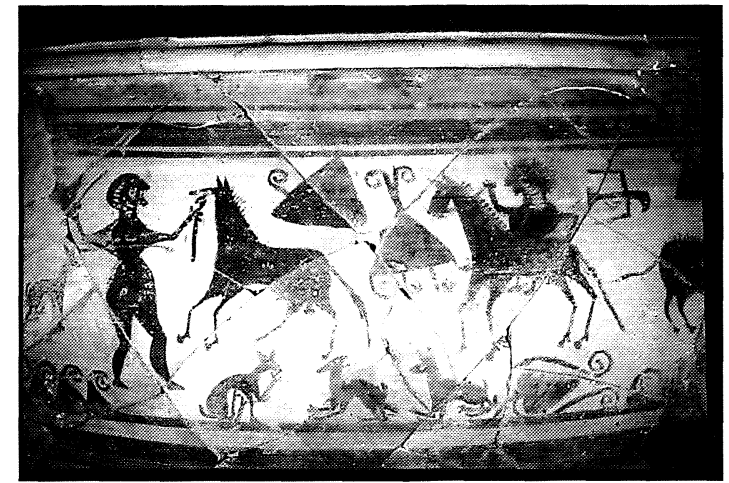

Fig. 6.-Detalle del vaso de la figura anterior, de San Miguel de Liria (Valencia). Escena de doma de caballo. Foto cortesía del S.I.P., Valencia.

caballo) o de dominio (la prueba del toro) y, en consecuencia, se dota de realidad precisa a los animales que respaldan las hazañas humanas. La naturaleza se distingue con rasgos reconocibles para describir la historia, un episodio del poder humano. Una singular graduación va definiendo la percepción y apropiación psicológica de la naturaleza por el pintor y su cliente: desde el animal familiar —el perro que se rasca (fig. 7) — al animal radicalmente salvaje y ajeno al hombre - el jabalí que es devorado por lobos y cuyas entrañas se muestran desgarradas (fig. 8) - pasando por los animales cuya dialogante relación con lo humano queda establecida en grados diversos: el caballo, que por intervención del

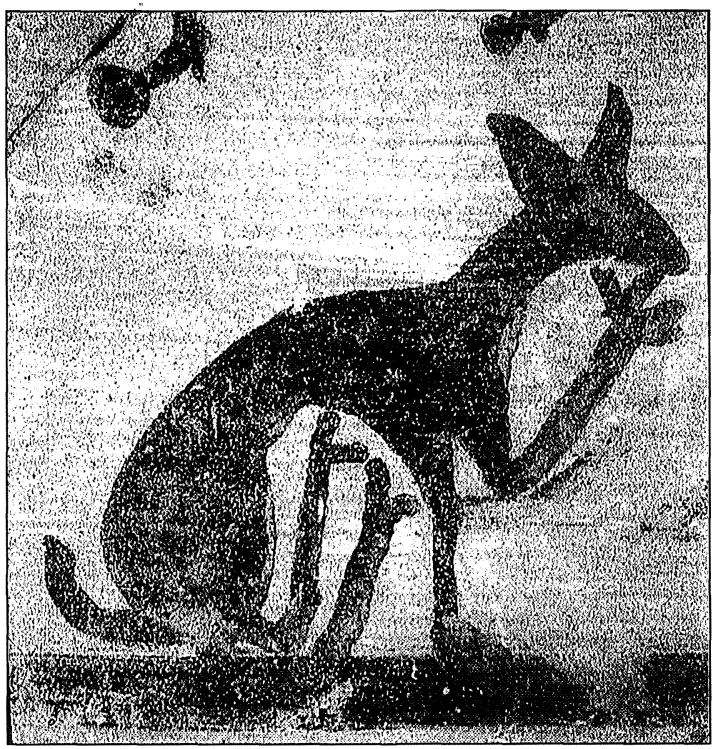

Fig. 7.-Perro rascándose. Detalle de la figura anterior, del vaso de San Miguel de Liria (Valencia). Foto cortesía del S.I.P., Valencia. 


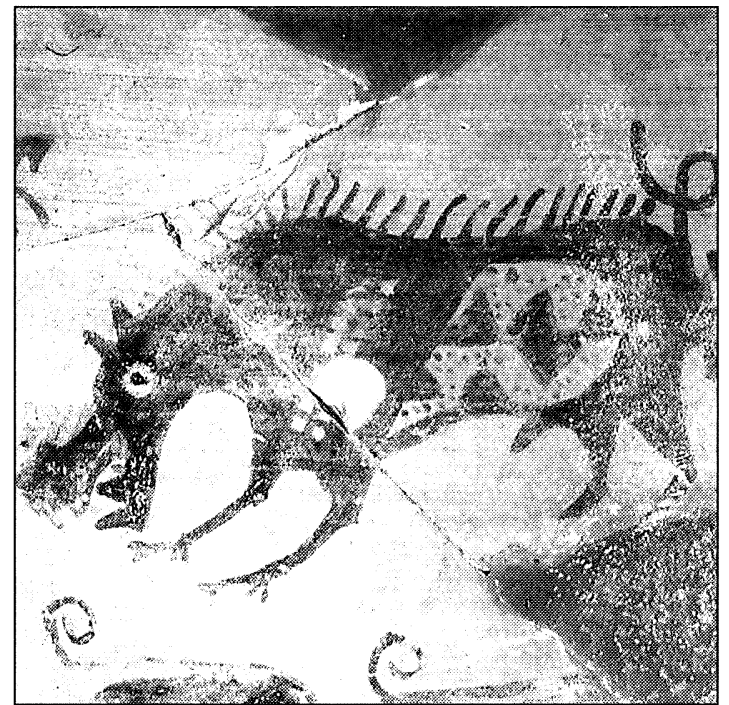

Fig. 8.- Jabalí con las entrañas desgarradas. Detalle del vaso de San Miguel de Liria (Valencia), reproducido en la figura 4. Foto cortesía del S.I.P., Valencia.

varón formará parte del ámbito doméstico, junto a los familiares perros (fig. 6); y el toro, cuyo dominio y apropiación ejercita el hombre (fig. 5). La naturaleza, múltiple y diversa, se describe por tanto desde su relación próxima o alejada, desde su cotidianidad o separación abismal, con el hombre. También en este vaso una última escena, la guerra reglada de los hombres, heroica (fig.6), se opone al salvaje despedazamiento de las fieras (fig. 8): es la regulación de la ciuitas frente al mos ferarum.

Esta observación nos permite, en nuestro nuevo caso de Valencia, situarnos en el espacio narrativo que desea comunicar el pintor. Y este espacio poblado de animales extraños es el del tiempo mítico, que multiplica los adýnata, las relaciones imposibles de la naturaleza hechas aquí posibles. Los frisos A y B deben leerse, por igual, en este tiempo de los orígenes. Todos - o casi todos - los seres representados pertenecen al linaje de los animales míticos. Nuestra relación con ellos no parte de una simple experiencia directa. Los transforma la imagen; los legitima el mito.

Los tres animales de la primera cara no se atacan sino que acuden al unísono (fig. 2). Algo les atrae. Cada uno de ellos se representa en sus gestos esenciales: la ferocidad del carnassier, con las mandíbulas abiertas y los dientes afilados; y el apresuramiento y fecundidad, del cuadrúpedo fugitivo. La acumulación de ubres, cargadas con el fluido interior zigzagueante, es expresión de esta fecundidad en que se sitúa nuestro episodio. Por último, hemos de aludir al gallo, que cubre el espacio entre ambos

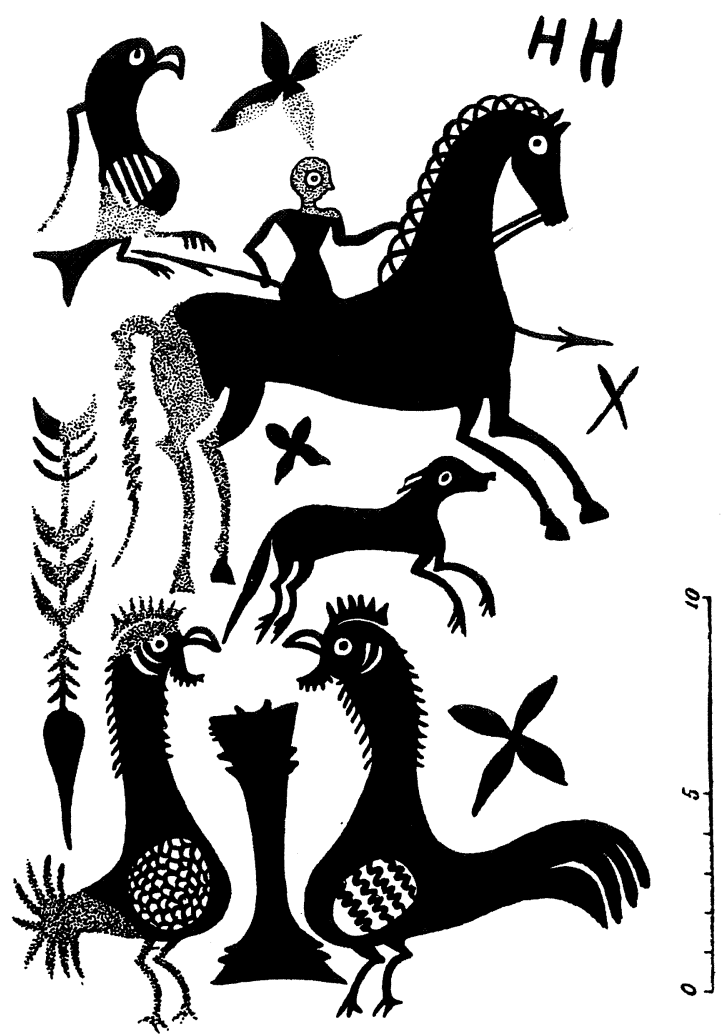

Fig. 9.- - Jinete y gallos afrontados a un timiaterio. Dibujo de $\mathrm{M}^{\mathrm{a}}$ de la Encarnación Cabré, según J. Cabré, Cerámica de Azaila. C.V.H., 1944, fig. 52.

cuadrúpedos. Es, sin duda, el animal más próximo a nuestro tiempo de percepción. Su aparición aquí es tanto más significativa cuanto es prácticamente desconocida su presencia en la cerámica ibérica del área valenciana. Se documenta, tardíamente, en las cerámicas del valle del Ebro (fig. 9) —en un momento más o menos coetáneo con nuestro ejemplo- y en las del interior, en ámbito celtibérico, asociadas posiblemente a temas solares y a presencias divinas ${ }^{9}$ : el cacareo del gallo anuncia la luz, provoca la llegada del sol ${ }^{10}$. Sendos gallos enmarcan, a ambos lados, un extraño templo con la imagen del dios en su interior, en un vaso del siglo i a.

\footnotetext{
${ }^{9}$ En la cerámica de Azaila (Teruel): pareja de gallos afrontados, heráldicamente, a un timiaterio, expresión de una presencia divina. Cf. J. Cabré, 1944, cit. (n. 6), p. 67, fig. 52. Cf., finalmente, el pito en cerámica, en forma de gallo de la Edad del Hierro, de Sepúlveda (Segovia): Juan F. Blanco García, «La Edad del Hierro en Sepúlveda (Segovia)», Zephyrus, 51, 1998, p. 158, con bibl. y fig. 16, 2.

${ }^{10} \mathrm{Cf}$. Manabu Waida, «Cocks» en M. Eliade (ed.) The Encyclopedia of Religion, vol. 3, Nueva York / Londres, 1987, pp. 551-552. Para la tradición griega, cf. el libro clásico de D'Arcy W. Thompson, A Glossary of Greek Birds, Londres 1936 (1. ${ }^{\mathrm{a}}$ ed. 1895), pp. 33-44. En el mundo céltico, cf. Miranda J. Green, Dictionary of Celtic Myth and Legend, Londres, 1992, pp. 62-3.
} 
de C. del yacimiento celtibérico de Arcóbriga, en Zaragoza ${ }^{11}$. Pero ¿por qué no acudir también al imaginario itálico coetáneo? ¿No se decía allí que el león huía a la vista del gallo? ${ }^{12}$. León y gallo, dos animales asociados, pues, en el universo popular que transmite el poeta Lucrecio: asociados en la fuerza, en el vigor, en el poder, desde esa contraposición paradójica que prima secretamente al animal de apariencia menor. Por tanto, en Valencia no ha de parecernos indigna ni secundaria $-\mathrm{o}$ meramente circunstancial y fugitiva- la presencia del gallo junto al enorme carnassier y al gran cuadrúpedo de las mamas. Puede anunciar un inicio, ser testigo de un evento inaudito, que provoca con su canto. Puede también asociarse, como en las restantes culturas mediterráneas, al certamen, a la lucha, a las divinidades guerreras ${ }^{13}$. Dejemos aquí abierta, con los obligados interrogantes, la posible apropiación ịbérica del motivo mediterráneo. En todo caso, esta secuencia de animales no resulta totalmente ajena a la construcción o sintaxis de la vieja tradición ibérica. La cerámica de Elche nos tiene acostumbrados a la coexistencia del carnassier o lobo y el águila, que despliegan simultáneamente su vitalidad, llenando ambos con sobreabundancia el espacio reservado a las imágenes. Animales fugitivos - aves, conejos...- y animales feroces coexisten en este mundo imposible. La insólita incorporación del gallo, con su marcado contraste de tamaño, entra, pues, en ese amplio paradigma de lo esperable al que estamos ya habituados en el mundo ibérico. Tampoco se antoja extraña la coexistencia de animales pacíficos y fieras en el imaginario poético y utópico del helenismo.

La lectura de la cara B es más compleja. Decimos que el protagonismo de la realización lo ocupa la figura híbrida (fig. 3). Insisto en que esta figura pertenece al mismo espacio y tiempo que los otros seres y que no hay un reino separado, dividido, entre «realidad»y «mito», por mucho que los otros animales puedan, en mayor o menor medida, ser identificados con especies reales e identificarse con

11 Juan Cabré, La necrópolis ibérica de Tútugi. Memorias de la Junta Superior de Excavaciones y Antigüedades 25. Madrid, 1920, p. 39, figs. 8 y 39; Gabriel Sopeña, Dioses, ética y ritos. Aproximaciones para una comprensión de la religiosidad entre los pueblos celtibéricos, Zaragoza, 1986, pp. 49-50, lám. 13; Luis Pericot, Cerámica ibérica, Barcelona, 1979 , p. 13, fig. 5a; Francisco Marco Simón, «Iconografía y religión celtibérica. Reflexiones sobre un vaso de Arcóbriga», en: Homatges a Miquel Tarradell. Estudis Universitaris Catalans, XXIX. Barcelona, 1993, pp. 537-551. Ricardo O1mos (coord.), Los Iberos y sus imágenes, CD-Rom, Micronet, S. A., Madrid, 1999, catálogo n. ${ }^{\circ} 99.1$.

${ }_{12}$ Lucrecio, De rerum natura, IV, 726.

13 Ares o Atenea en el mundo griego.

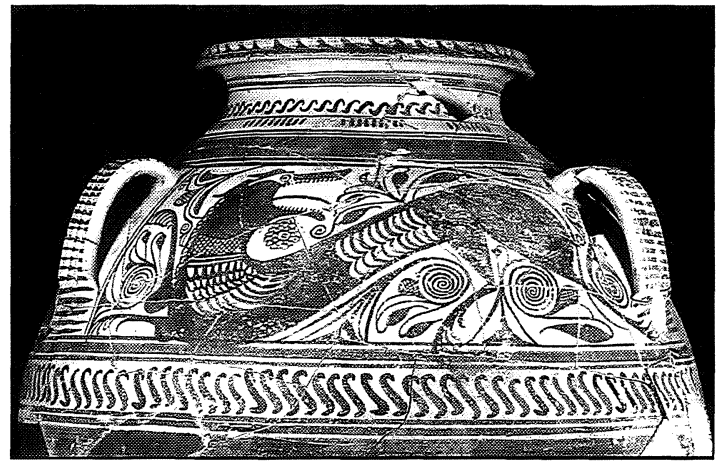

Fig. 10.-Lobo de cuerpo extraordinariamente alargado, con el vientre apoyado sobre el suelo, de un vaso cerámico de $\mathrm{La}$ Alcudia de Elche (Alicante). Museo monográfico de La Alcudia, Elche. Foto «Proyecto de iconografía ibérica», Instituto de Historia, CSIC.

nuestro mundo de experiencias. Es solamente dentro de ese ámbito común donde el monstruo queda enfatizado y singularizado: de ahí el arbusto que lo separa del cuadrúpedo (fig. 4). Actúa como sugerencia espacial ${ }^{14}$.

La figura híbrida es un ser metamórfico. No pertenece ni a la tierra ni al mar. O tal vez pertenece a ambos reinos pues de ambos toma elementos para existir. Su cuerpo delantero es de ketos, pero su mitad trasera es de cuadrúpedo, de caballo. ¿Cómo moverse? ¿Qué hacer para sostenerse fuera del agua? La parte anterior carece de patas y ha de apoyarse en la línea del suelo sobre el redondeado vientre, como de forma similar hacen los grandes lobos de cuerpo extraordinariamente alargado en la cerámica de La Alcudia de Elche (fig. 10). Es un adýnaton, ser imposible de miembros discordes, carentes de lógica y de movilidad. Nos hallamos, pues, frente a uno de esos animales no viables de los orígenes, de tamaño descomunal, asexuados y sin los órganos necesarios para la locomoción ${ }^{15}$.

${ }^{14}$ La función del elemento vegetal vertical que, al modo de un arbusto, separa al ser monstruoso del cuadrúpedo que le sigue, parece al tiempo tectónica y simbólico-espacial: arropa y aisla a la «cierva» semiescondida, y también resalta al ketos individualizando, con ello, el espacio del evento maravilloso y único que tiene lugar en esta escena, al modo de un énfasis o intensificación. Como veremos, puede ayudar a indicar el límite del espacio de la tierra frente al del mar. Han de entenderse, sin embargo, con función tectónica las dos bandas verticales junto a las asas, a la izquierda de cada friso: refuerzan la articulación de las asas; no separan, como se me ha apuntado oralmente en Valencia, ambas caras, que en mi opinión han de leerse como sendas unidades de un mismo conjunto.

${ }_{15}$ Compárese con los andróginos inviables de Lucrecio, De rerum natura $\mathrm{V}, 837$ ss.: «Y muchos entonces la tierra también tentó de criarlos / monstruos de faz asombrosa y de miembros mal amasados: / el hembrimacho, entre lo uno y lo 
Su único lugar imaginable es, en consecuencia, el límite entre la tierra y el agua que supera el puente o arco de su estirado cuerpo. Su hibridación es tanto somática como espacial. Expresa al monstruo indígena, el que nace y vive exclusivamente en el lugar desde los tiempos originarios, antes de aparecer la raza de los hombres ${ }^{16}$. Define míticamente un territorio.

La segunda observación es la expresión del cuerpo como vehículo, un vehículo marcadamente alargado, fuera de toda proporción, adecuado al tamaño mayor de los seres de antaño: la tierra originariamente parió enormes cuerpos de bestias ${ }^{17}$. Un cuerpo así ha de compartimentarse en segmentos, como hemos visto en las otras figuras de la cara anterior. Se articula en secciones, y para construirlo, el pintor incorpora elementos geométricos de las propias metopas del vaso, como los triglifos y el relleno geométrico a mitad del cuerpo.

La tercera observación es que vemos lo que ocurre en su interior. Éste es un rasgo que este vaso comparte con otros ejemplos: se integra en una tradición latente de la iconografía ibérica, aunque jamás tan explícita como en este caso. Conocemos especialmente por representaciones cerámicas este procedimiento. Frente al arte clásico de tradición grecorromana, que muestra por lo general la apariencia exterior de los seres, su piel, al pintor ibérico, con relativa frecuencia, le preocupa la figuración de las entrañas, la naturaleza interior de los seres, como si de una radiografía se tratara: así, en algún plato de pescado, se representa la espina de los peces y, con ella, su voracidad ${ }^{18}$; en los lobos, las entrañas devoradoras, las costillas ${ }^{19}$; aquí, como si su piel fuera transparente, los seres que este monstruo

otro y ninguno de ambos, / faltos de piernas acá, por allá privados de brazos, / mudos sin boca también, sin cara ciegos por caso / y atados por todo el cuerpo de miembros apegotados, / que ni hacer cosa pudieran ni echar a su sitio paso / y ni su daño esquivar ni lo de provecho tomarlo, / y más por este jaez criaba engendros y espantos» (traducción de A. García Calvo).

${ }^{16}$ Para los seres indígenas previos al linaje humano, cf. el relato de Evandro a Eneas en Eneida, VIII, 314 ss.

17 Lucrecio, ibid. II, 1150 ss.: «... agotada la tierra apenas si cría animales pequeños, habiéndolos ella sin tasa criado y parido enormes cuerpos de bestias»; ibid. V, 799-800: «y muchos aún hoy animales se ven que de tierra se crean (...); tanto es menos de asombro que más entonces surgieran,/ más grandes también, nueva siendo y crecida la tierra» (traducción de A. García Calvo).

${ }_{18}$ Ex gratia, H. Bonet, 1995, cit., (n. 8), p. 90, fig. 27.

19 Ex gratia, el lobo en el Vaso de los Guerreros de Archena, cf. R. Olmos, «Posibles vasos de encargo en la cerámica del Sureste», $A E s p A, 60,1987$, pp. 21-42, fig. 9. Sin embargo en la representación de las costillas de los lobos hay un compromiso entre el interior devorador y el aspecto exterior del animal hambriento, famélico, con las costillas acentuadas. lleva en su interior. Es una forma analítica de concebir la imagen, que se basa en la alternancia y simultaneidad de la silueta y del contorno: la silueta negra representa el volumen global de las figuras; el perfil del contorno permite analizar sus partes constitutivas, su definición precisa, su actividad. No es éste un rasgo superfluo sino que se integra necesariamente en el procedimiento narrativo. Resulta aquí necesario para explicar la identidad y la función mítica de esta figura.

Y lo que lleva en su interior es, como en una matriusca rusa, un monstruo similar, pero más diminuto, en el mismo gesto que - en este instante, al menos- su progenitor: con la singular jabalina o arpón levantado en su derecha ${ }^{20}$ y el gesto de la diestra erguida, gesto al que estamos habituados por tantos exvotos ibéricos o por tantos vasos con representación humana. Se trata de una gesticulación viva, que expresa posiblemente una actitud de intervención, de acción, de vitalidad, de incipiente humanidad.

El ser híbrido se repite, ya fuera del monstruo, en la parte inferior del vaso, llenando el espacio del vientre y en similar actitud. Tal vez, el objeto oblongo junto a su mano, bajo el vientre del gran monstruo, sea un gran huevo, germen sustentador de la vida ${ }^{21}$. En el lenguaje de este vaso difícilmente tiene cabida la otra opción: que se trate de un brote, de una planta. Decíamos antes que el universo vegetal carece de voz propia, de protagonismo, en esta representación.

Pero la mayor dificultad del monstruo principal la ofrece la parte anterior. Por eso la he dejado para el final. Hay diversas opciones y ninguna de ellas sin problemas. La primera es la que hemos aceptado implícitamente hasta este momento: que es un ser metamórfico, híbrido, compuesto de parte anterior humana y posterior animal, igual que el ser que lleva dentro o como el que está bajo su vientre, en una repetición a mayor o menor escala. En este caso, los dos círculos reservados en su parte delan-

${ }^{20}$ Me indica amablemente Fernando Quesada que el arma que sostienen los monstruos difícilmente tiene algo que ver con lo que conocemos de las armas reales ibéricas, como lanzas o jabalinas. Las aletas abiertas de la punta insinúan, en todo caso, la función tal vez de un arpón. El arpón conviene mejor a ese espacio mítico, fluvial o marino, de esta cara del vaso: no sería arma para luchar con hombres, que en ese momento primordial aún no existen, sino para enfrentarse a animales o monstruos marinos, para pescar.

${ }^{21}$ Este elemento es asociable a los círculos ovalados que decoran la parte trasera de los cuadrúpedos y que vemos en las aves de la cerámica de Azaila. Cf. supra nota 6. Habría que estudiar en otro lugar la posible relación de estos rasgos en el lenguaje pictórico de estos vasos tardíos del valle del Ebro y Valencia. 
tera representarían las improbables mamas. Una primera dificultad: son demasiado pequeñas para un ser tan grande y en función de procrear. Además: ¿cómo conciliar estas dos mínimas protuberancias con las exageradas ubres de la yegua de la otra cara? El ceramista no puede cometer tamaña contradicción.

Tanteemos, por tanto, una segunda opción: aceptar que estamos ante el instante de un nacimiento y que lo que vemos es un personaje que está surgiendo de la gran boca de un ketos o monstruo asexuado. Desde esta lectura los círculos no son los pechos sino grandes ojos frontales, junto a la apertura creadora del inmenso bostezo o chasma de una boca dilatada y redonda. En el interior tal vez adivinamos el vestido talar y los pies, esquemáticos, mal definidos, de una figura humana: casi aletas. Es difícil aquí precisar más. En todo caso, lo esencial: se estaría contando bien el surgimiento - o bien, su contrario, el devoramiento- a través de la gran boca abierta del monstruo de un ser mítico, cubierto con casco de piel y armado con jabalina acuática ${ }^{22}$. Un ser mítico que vemos, por primera vez, casi con forma humana en un mundo aún de bestias, more ferarum, con el que hay que convivir ${ }^{23}$.

Puede tratarse de una figura femenina, adornada con dos filas de colgantes, al modo de un doble collar de finas lengüetas; o un ser marino con el busto escamado. El imaginario ibérico nos ha acostumbrado ya a la imagen de la diosa armada y protectora: en acuñaciones monetarias y terracotas republicanas de la Hispania Ulterior, especialmente la Bética ${ }^{24}$,

${ }^{22}$ Otra opción no descartable es la que ve en el gesto ambiguo de la gran boca abierta un gesto de devorar, no de devolver hacia el exterior. Así me lo han sugerido tanto Carmen Aranegui en el seminario de Valencia, como Teresa Chapa en Madrid. En este devorar el monstruo transformaría, a través de su cuerpo, al ser devorado, convirtiéndolo en imagen de sí mismo. Los seres, así formados en el vientre del monstruo, surgirían por la parte posterior del animal como indica la pata del feto abriéndose paso por la vagina del monstruo, rasgo intencional (indicación oral de T. Chapa). La objeción es certera y modifica —o hace más insegurasmis conclusiones. Pues desde esta opción alternativa, anterior a la historia, el cosmos humano se transformaría en monstruo mixto, a la vez humano y teriomorfo. Pero el movimiento general de las figuras en el vaso se dirige unitaria e insistentemente hacia la derecha. Entiendo así la coherencia de la totalidad y mi discurso se mueve preferentemente en la opción del engendrar por la boca al primer ser humano. Dejémoslo en todo caso abierto.

${ }_{23}$ Michel Serres, El nacimiento de la física en el texto de Lucrecio. Caudales y turbulencias, Edit. Pretextos, Valencia, 1994, p. 209: «Las bestias pertenecen al nicho humano, pero el hombre forma parte del nicho de los animales».

${ }^{24}$ R. Olmos, «Usos de la moneda en la Hispania prerromana y problemas de lectura iconográfica», en: M. ${ }^{\text {a }}$ Paz García-Bellido, La moneda hispánica. Ciudad y territorio, Anejos de AEspA; XIV, 1995, pp. 41-52, espec. p. 49.

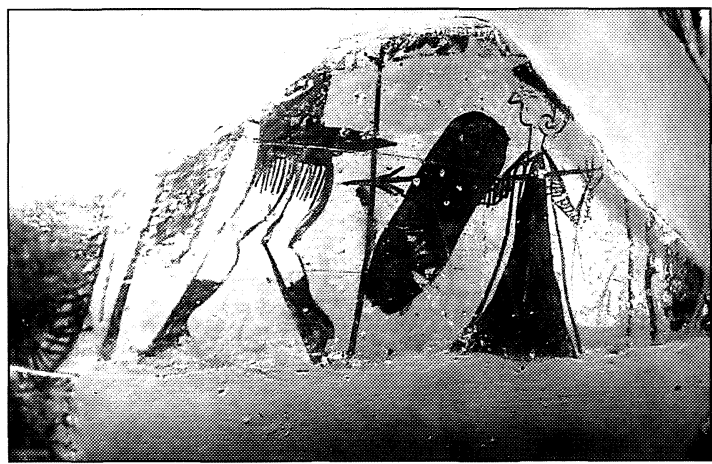

Fig. 11.-Posible efigie de divinidad femenina armada. Detalle de un gran vaso ibérico de Oliva (Valencia). Museo Nacional de Arqueología de Cataluña, Barcelona. Foto cortesía del Museo.

pero también de la Citerior: una cabeza galeada, a la que se ha llamado Roma, decora precisamente las emisiones de bronce de la Valentia republicana ${ }^{25}$; en el gran vaso de Oliva (Valencia), acaso como efigie, como palladium ${ }^{26}$ (fig. 11); o en la Minerva esculpida sobre la muralla de Tarragona, signo que simultáneamente funciona como mensaje para indígenas e itálicos ${ }^{27}$. Sin embargo, algunos de estos ejemplos pertenecen a un ámbito religioso diferente, el que Marco Terencio Varrón, en sus libros de antigüedades divinas, llamó «teología civil», la que definen los legisladores de los estados. Al contrario que las monedas, nuestro vaso puede reflejar una religiosidad menos oficial, la «teología mítica» de los poetas de la aludida clasificación tripartita de Varrón ${ }^{28}$. La aproximación de la posible imagen femenina a la acuñación de Valencia queda así mitigada. Es de otra esfera.

Pues nuestro vaso cuenta un mito del lugar, habitado por el gigantesco monstruo indígena, inamovible, que pertenece a sus orígenes más remotos.

${ }^{25}$ Pere Pau Ripollés, La ceca de Valentia, Conselleria de Cultura de la Generalitat Valenciana, estudios numismáticos, n. ${ }^{\circ}$ 2, Valencia, 1988. Lleandre Villaronga, Corpus Nummum Hispaniae ante Augustae Aetatem, Madrid, 1994, pp. 317-8.

${ }_{26}$ Les Ibères, París-Barcelona-Bonn, 1997-1998, p. 245 n. ${ }^{\circ}$ 36. R. Olmos, Los Iberos y sus imágenes, 1999, cit. (n. 11), n. ${ }^{\circ} 80.1$.

${ }_{27}$ Wilhelm Grünhagen, «Bemerkungen zum Minerva-Relief und der Stadtmauer von Tarragona», Madrider Mitteilungen, 17, 1976, pp. 209-225; Michael Blech, «Minerva in der republikanischer Hispania», en: Praestant interna. Festschrift für Ulrich Hausmann. (Eds. B. von Freytag gen. Löringhoff, D. Mannsperger y F. Prayon), Tübingen, 1982, pp. 136-145, espec. pp. 136-140, fig. 1. R. Olmos, Los Iberos y sus imágenes, 1999, cit. (n. 11), n. ${ }^{\circ} 94.2 .1$.

${ }_{28}$ Sobre la teología de Varrón cf. Pierre Boyancé, La religion de Virgile, París, 1953, p. 17; Jean Pépin, Mythe et allégorie, París, 1958, p. 276 ss. La tercera teología, la natural, es la de los filósofos. 
Asistimos a su metamorfosis, que enlaza el mundo plenamente animal con el primer asomo humano. El monstruo es asexuado y autómatos, espontáneo: se basta a sí mismo. Va engendrando, a sucesivos seres, iguales o semejantes a él, que nacerían armados, uno tras otro, sin parar. En el momento decisivo que narra el vaso, de la boca surge -o, al contrario, desde la lectura opuesta que se me ha propuesto, engulle y transforma- el personaje singular, humano, que comparte el espacio con los otros animales y monstruos del vaso. Sea como sea - deglución, expulsión o ambas cosas- en el vientre del monstruo se gestan los incrementa o gérmenes del futuro pueblo del lugar, que nacen belicosos y marinos, blandiendo las armas, como en el mito de Cadmo ${ }^{29}$.

Es un universo fecundo, en gestación, in fieri, en surgimiento, movimiento, lucha. Conocíamos ya variantes o ecos lejanos de este motivo en la cerámica de Elche, con el surgimiento de lobos y águilas en acción, mostrando su naturaleza vital y agresiva ${ }^{30}$, y en un singular vaso de Liria al que luego aludiré. Pero nuestro vaso es más explícito y su contenido es único. Está muy alejado del estilo narrativo de los vasos de San Miguel de Liria, en Valencia, un siglo anteriores (inicios del II a. de C.) que relatan rituales de iniciación y de cohesión de grupos sociales aristocráticos, masculinos y femeninos, de una comunidad: danzas, enfrentamientos, ritos funerarios, cazas... ${ }^{31}$. Algunas de estas escenas aluden posiblemente a la realidad a través de modelos míticos, como en el citado vaso de Liria con la iniciación de los jóvenes en la doma y en el mundo que pone en relación el ámbito civilizado, de los hombres, con el de la naturaleza salvaje y animal (figs. 5-8). Pero son vasos, sobre todo, con escenas que articulan y relacionan grupos sociales aristocráticos en torno al género y a la edad, como ha estudiado Carmen Aranegui ${ }^{32}$. La misma forma de ciertos vasos de esta serie responden a una cratera sin asas: es seguramente el gran vaso de bebida colectivo, el recipiente idóneo donde reflejar estas fiestas heroicas en torno al antepasado común, a reuniones reguladas de mujeres, a rituales de caza e iniciación

${ }^{29}$ Cf. Ovidio, Metamorfosis, III, v. 99 ss.; v. 103: «populi incrementa futuri».

${ }^{30}$ Ex gratia, R. Olmos, Los Iberos y sus imágenes, 1999, cit. (n. 11), n. ${ }^{\circ}$ s. 46.3; 69.1-3, etc.

${ }^{31}$ Carmen Aranegui, «La sociedad ibérica vista a través de las imágenes sobre cerámica de Llíria», en: C. Aranegui, (ed.), Damas y caballeros en la ciudad ibérica: las cerámicas de Llíria (Valencia), pp. 161-175. Cátedra. Historia/ Serie Menor. Madrid; Helena Bonet, 1995, cit. (n. 8), passim.

${ }^{32}$ Cf. nota anterior; Carmen Aranegui, Escenas de la ciudad ibérica. Colección Eutopías. Ed. Episteme. Valencia, 1997.
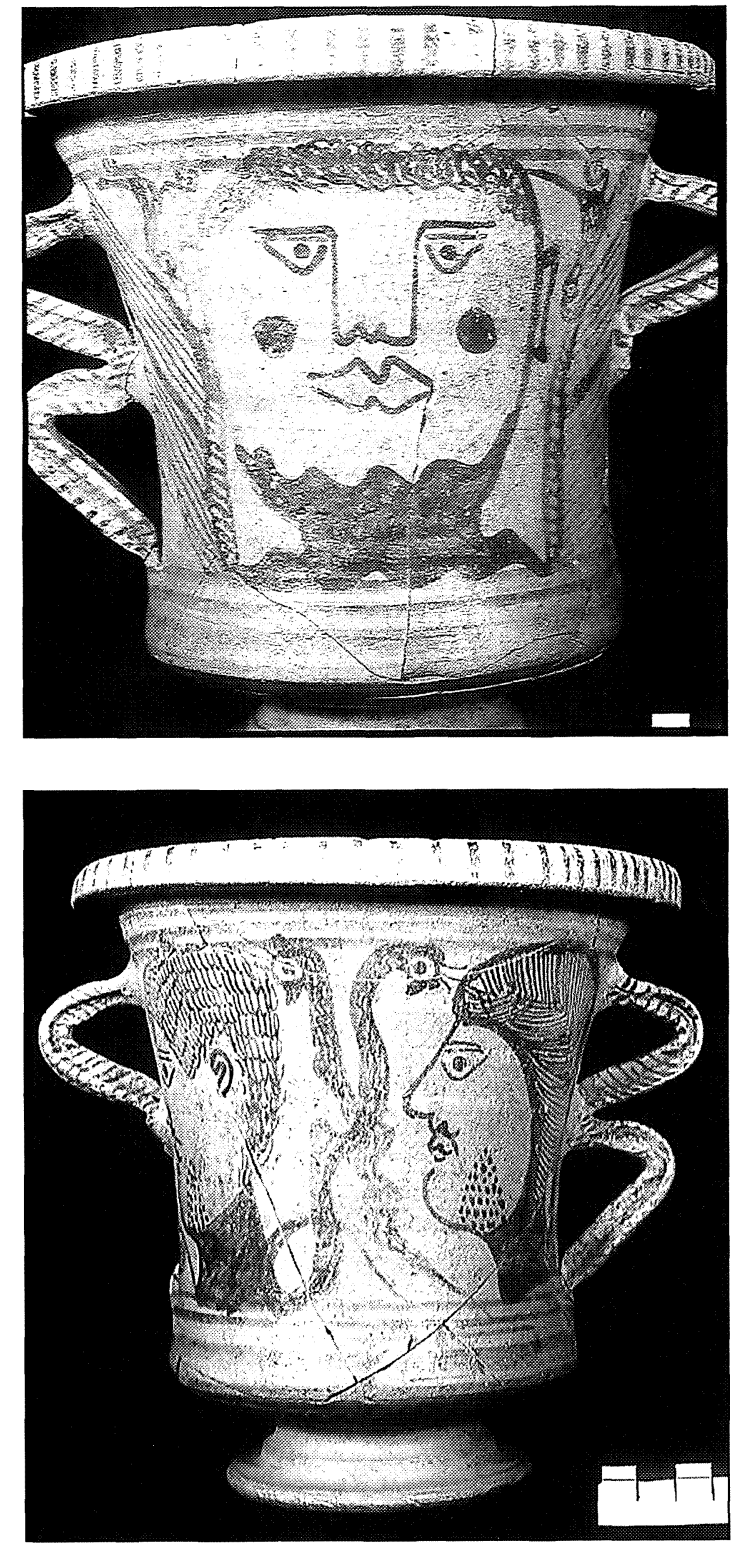

Figs. 12 y 13.-Craterisco iberohelenístico de La Alcudia de Elche (Alicante). Museo monográfico de La Alcudia, Elche. Anverso: Divinidad femenina surgiendo de la tierra; reverso: dos bustos de varón barbados, de perfil, entre serpientes. Foto «Proyecto de iconografía ibérica», Instituto de Historia, CSIC.

de jóvenes, a grupos guerreros en que se articula el mundo de los poderosos, etc. ${ }^{33}$.

Todos estos vasos de Liria, digo, son al menos anteriores en un siglo al que ahora describimos y responden a una forma de autorepresentación del

${ }^{33}$ R. Olmos, «Naturaleza y poder en la imagen ibérica». Cf. supra, nota 8. 
poder aristocrático de un gran oppidum ibérico en torno al 200 a. de C. Algunos de estos vasos se han encontrado reunidos, atesorados, en áreas consideradas sacras y de poder en la ciudad, como felizmente destacó Helena Bonet en $1992^{34}$.

Junto a esta serie específica de Liria hay otro grupo, aún pequeño, de vasos que describen probablemente mitos de orígenes, escenas que nos transportan al tiempo primordial. Algunos de ellos reflejan motivos de autoctonía, escenas de nacimiento de la divinidad femenina del lugar como en el conocido craterisco de La Alcudia de Elche, un vaso ibérico, al parecer tardío, como el ejemplar de Valencia $^{35}$ (figs. 12 y 13). En uno de sus lados, un inmenso rostro de una diosa brota de la tierra en la que arraiga. Cuello y barbilla, en negro, aluden probablemente a las bifurcaciones raigales y telúricas. En su surgimiento la cabeza desborda el panel del vaso, lo que es propio de las epifanías. Además, en el tiempo de los orígenes todo solía manifestar un mayor tamaño. La cabeza es atendida por dos aves, una de las cuales dialoga con la diosa transmitiéndole en el oído un mensaje. En el reverso, dos bustos de varones de perfil, que surgen entre serpientes, acompañan a la diosa frontal, son testigos de su nacimiento. Aquí tenemos probablemente un mito que alude a los orígenes divinos del lugar, tal vez una escena de autoctonía. El vaso de Valencia, sin embargo, es diferente en su significado.

No es más próximo por su estilo, aunque hallemos ecos o asociaciones temáticas, el gran vaso hallado en el poblado ibérico de los Villares, en Caudete de Las Fuentes (Valencia) donde un descomunal monstruo marino, que viste túnica larga, con cinturón y gorro puntiagudo, se enfrenta en la lucha con un hombre ${ }^{36}$ (fig. 14-16). Una imagen grande requiere un recipiente grande. El monstruo, aparentemente asexuado, tiene naturaleza metamórfica, escurridiza, como los seres proteicos del agua, y a él se asocian una especie de «esfinge» o «centauro», y un lobo, que le tocan con sus garras y le infunden

${ }^{34}$ H. Bonet, «La cerámica de S. Miguel de Liria: su contexto arqueológico valenciano», en $\mathrm{R}$. Olmos et al., La sociedad ibérica a través de la imagen. Ministerio de Cultura, Barcelona, 1992, pp. 224-236.

35 R. Olmos, «El rostro del otro. Sobre la imagen de la divinidad en la cerámica ibérica de Elche», $A E s p A, 65,1992$, pp. 304-308; Trinidad Tortosa, en: Hombres sagrados. Dioses humanos, Madrid, 1999, pp. 134-135.

${ }^{36}$ Enrique Pla y Albert Ribera, Los Villares (Caudete de las Fuentes, Valencia). Comunicaciones del Servicio de Investigaciones Prehistóricas. Trabajos varios n. ${ }^{\circ} 68$. Valencia 1980, p. 99, fíg. 11, lám. 42; R. Olmos, Los Iberos y sus imágenes, 1999, cit. (n. 11), n. ${ }^{\circ}$ 84.5. Finalmente, Othmar Jaeggi, Der Hellenismus auf der iberischen Halbinsel, Mainz am Rhein, 1999, p. 209, n. ${ }^{\circ}$ 69, fig. 33: «Gigantomaquia».
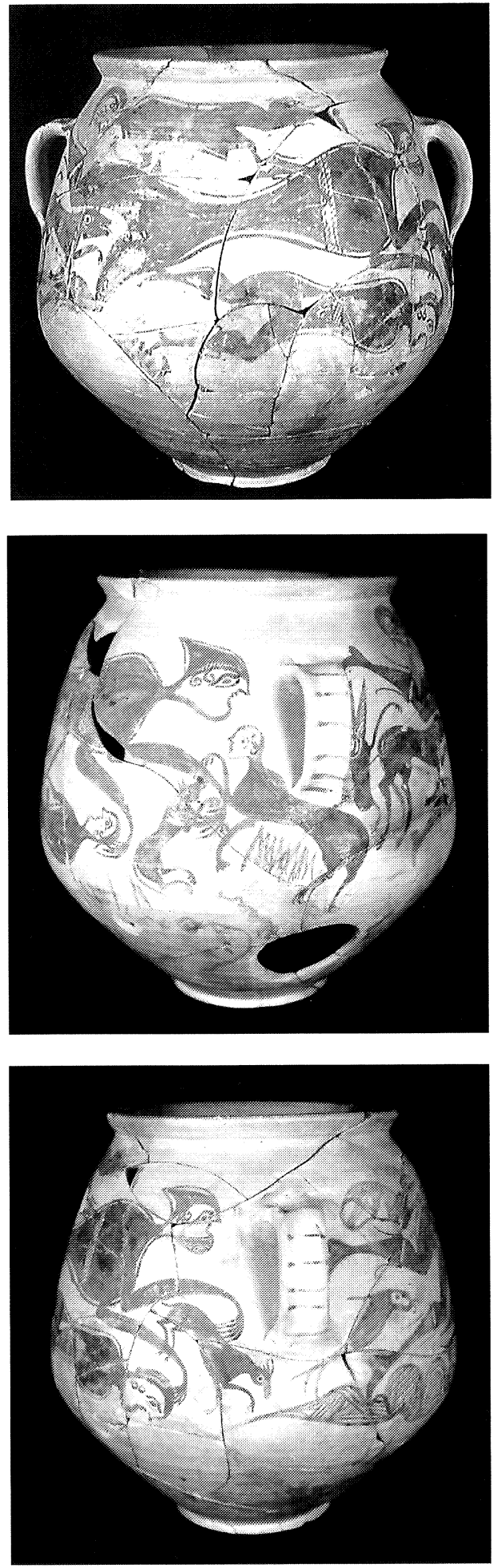

Figs. 14-16.-Gran ánfora ibérica de los Villares (Caudete de las Fuentes, Valencia) con combate mítico contra un enorme ketos o monstruo marino. Museo Arqueológico de Caudete de las Fuentes (Valencia). Fotos cortesía del S.I.P., Valencia. 
su inagotable vigor (fig. 15). El tamaño menor de estos animales sirve de escala o referencia a la magnitud insólita del monstruo. Pues lo gigantesco como esencia y definición de lo monstruoso (una caracterísitica habitual de portentos y prodigios) es común a estos vasos ibéricos de mirabilia de época republicana. Las dos caras del gran vaso de Caudete insisten en el mismo tema. La repetición del motivo no es trivial sino intencionada: puede servir para intensificar la acción; magnifica, pues duplica, la inmensidad y poder del ketos. Dos veces es herido con un puñal por sus oponentes: en una pierna y en el pecho. Y un varón, representado sin brazos, yace boca abajo, ya vencido. Un delfín y una flor ondulada sugieren el mar, el reino de los seres proteicos y fluidos que continuamente se transforman ${ }^{37}$ (fig. 16). También lo sugiere la horizontalidad de los personajes humanos y del certamen, que exige un medio líquido. Este vaso sitúa, pues, la lucha en el espacio marino, lugar por excelencia de encuentros míticos. Otros vasos, en cambio, (como los fragmentos del Corral de Saus, en Valencia ${ }^{38}$; o el vaso del joven y el dragón de Elche ${ }^{39}$ ) sitúan el encuentro del hombre y el monstruo en un paisaje de tierra, con profusión vegetal, que alude a la exuberancia de la naturaleza salvaje que es testigo de la hazaña solitaria e iniciática. Repito que tanto el paradigma como el estilo de todos estos vasos son muy diferentes al vaso de Valencia. Sólo la singularidad temática indica cierta relación, cierta intención mítica innovadora que podríamos asociar. Estamos ante la necesidad de narrar temas nuevos, de contenido mítico muy diverso, en grandes vasijas cerámicas pintadas. Estas escenas tienen en común la contraposición y enfrentamiento del hombre con una naturaleza extraordinaria y sobrehumana. Aluden posiblemente a un tiempo de los orígenes. Expresan la apertura imprevisible de la historia, acrecentada políticamente por la experiencia, por la ruptura que representa Roma.

El gran vaso del monstruo marino del poblado ibérico de Caudete, aunque mal conocido contextualmente, debe corresponder también a una época tardía, al menos la segunda mitad del siglo II a. de C., es decir en plena época de la conquista de His-

${ }^{37}$ El delfín es la representación misma del mar; la flor su expresión de fecundidad. Para el delfín, expresión del mar, cf. Christian Zindel, Meeresleben und Jenseitsfahrt, Zürich, 1998.

${ }^{38}$ Isabel Izquierdo, «Reminiscencias mediterráneas en cerámica ibérica. El ejemplo de Corral de Saus (Mogente, Valencia)», $A E \operatorname{spA}, 69,1996$, pp. 239-261; R. Olmos, Los Iberos y sus imágenes, 1999, cit. (n. 11), n. ${ }^{\circ} 84.4$

${ }^{39}$ R. Olmos, Los Iberos y sus imágenes, 1999, cit. (n. 11), n. ${ }^{\circ} 84.2$, con bibl. y otros paralelos.

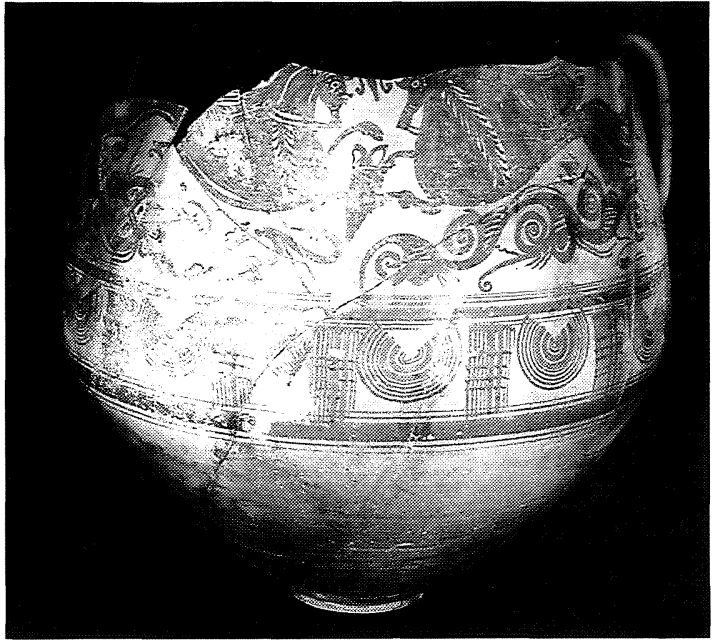

Fig. 17.-Gran ánfora ibérica de los Villares (Caudete de las Fuentes, Valencia) con hipocampos sobre el mar, afrontados a un ánfora. Museo Arqueológico de Caudete de las Fuentes (Valencia). Foto cortesía del S.I.P., Valencia.

pania por Roma. De esta época ha de ser también el vaso de este mismo yacimiento con hipocampos, dos de ellos afrontados a un ánfora que saltan sobre un metamórfico mar fecundo, indicado por los roleos vegetales, un tercero viajando hacia la derecha, hacia la $\operatorname{costa}^{40}$ (fig. 17). Es un mar de comercio, frecuentado por marinos, nos indica el ánfora que protegen los caballos del mar. En este vaso se está construyendo una mitología heroica propia sobre motivos iconográficos mediterráneos: los hipocampos heráldicos en torno a un vaso son familiares al arte helenístico. Se documentan, por ejemplo, en sarcófagos etruscos. La otra cara de esta gran vasija continúa la narración con una escena ya del ámbito terrestre con un jinete heroizado (fig. 18). Los roleos surgen ahora verticales, a la derecha del grupo: aquí indican la tierra, son naturaleza espontánea, vegetal. Pero no falta una alusión al mar. Bajo las patas del caballo, un ser con cola y aletas, probablemente una foca, acompaña al jinete. Señala el lugar de transición, el lugar de encuentro del mar y la tierra, la playa; simboliza el espacio, como en el vaso

${ }^{40}$ Enrique Pla y Albert Ribera, 1980, cit. (n. 36), p. 99, fig. 12; R. Olmos, Los Iberos y sus imágenes, 1999, cit. (n. 11 ), n. 67.2 ; R. Olmos, «Naturaleza y poder en la imagen ibérica», 1998, o.c. (n. 8), p. 150, figs. 5-6. La imagen marina debe ponerse en relación con un segundo vaso (bitroncocónico) con hipocampos, de La Carencia (Turís, Valencia) con hipocampos. Cf. D. Serrano Varez, Yacimientos ibéricos y romanos de la Ribera (Valencia), 1987, pp. 46 ss., fig. 3. Para estos dos vasos véase finalmente, Othmar Jaeggi, 1999, cit. (n. 36), n. ${ }^{\circ} 37$, fig. 15 (La Carencia) y n. ${ }^{\circ} 68$, fig. 33 (Los Villares de Caudete de las Fuentes). 


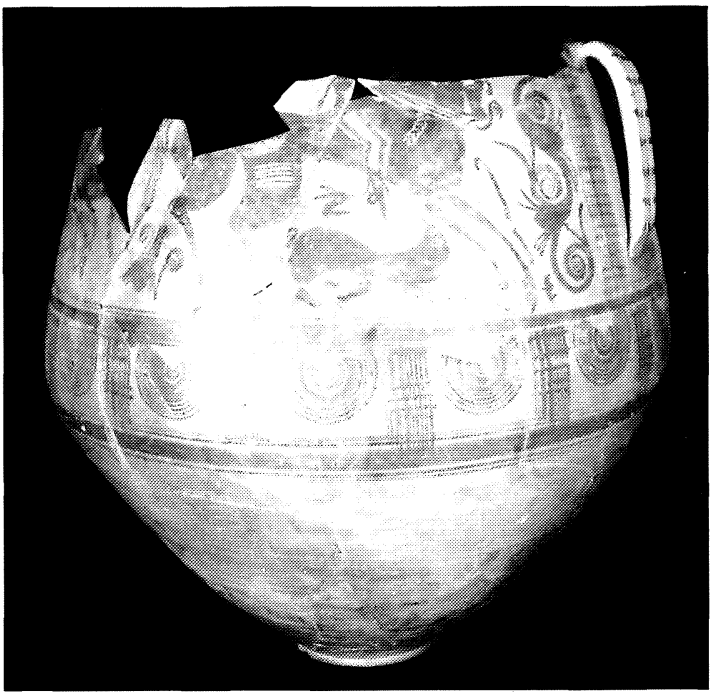

Fig. 18.-Reverso del vaso de la figura anterior con la representación de una playa mítica. Jinete y, bajo las patas del caballo, foca. Foto cortesía del S.I.P., Valencia.

de Valencia, el ubicuo monstruo engendrador. El jinete proviene del mar y se introduce en la tierra: es el momento crucial del tránsito al nuevo estado. Se utilizan motivos grecoitálicos (los hipocampos) para expresar una idea soteriológica mediterránea desde una expresión local: el viaje o iniciación marina de un personaje que accede triunfante a un nuevo lugar, a una tierra de bienaventuranza y fecunda, bajo la condición de jinete heroico, la tradicional fórmula ibérica que exalta al varón en su caballo. En la antigüedad no era tema inaudito el viaje por mar de las almas a las islas de los bienaventurados: se extiende en Grecia y en Roma, en ámbitos aristocráti$\cos ^{41}$. A inicios del siglo i a. de C. relatos de marinos sobre unas islas sin viento y sin lluvia que eran morada de los bienaventurados sedujeron a Sertorio ${ }^{42}$. Un deseo maravilloso de vivir una vida apacible en aquel lugar de fecundidad espontánea se apoderó del caudillo romano. La historia, de raíz odiseica ${ }^{43}$, era bien conocida en el extremo occidente en la época de esta escena mítica de Caudete, que posiblemente nos brinda una variante ibérica de las fortunatorum insulae. Señalemos aquí una dife-

${ }^{41} \mathrm{H}$. Wagenwort, «The journey of the souls of the dead to the isles of the blessed», Mnemosyne, 24, 1971, pp. 113-161; Christian Zindel, 1998, cit. (n. 37), p. 189, pp. 191 ss.; para el mundo romano, cf. Bernard Andreae, «Studien zur römischer Grabkunst», Römische Mitteilungen, Ergänzungsheft 1963, pp. 131 ss., especialmente p. 134. Recuérdese este motivo en los memorables versos de Horacio: «arva beata / petamus, arva divites et insulas» (Epodo, XVI, 41-42)

${ }^{42}$ Plutarco, Sertorio, 8, 2-5.

43 Odisea, 4, 563-569. rencia esencial con el vaso de Valencia: en el ejemplo de Caudete el movimiento de los seres va del mar a la tierra; los seres híbridos de un mar florido y fecundo propician el viaje del jinete al lugar maravilloso. En Valencia es al contrario: el movimiento unísono de los animales fecundos y asombrados de la tierra nos guía inequívocamente al monstruo.

Estamos, pues, en un momento muy receptivo del ámbito ibérico hacia los motivos formales e ideológicos itálicos: el siglo il a. de C., o el tránsito del siglo II al I. Me parece significativo que la eclosión mítica que muestran estos vasos de encargo se extienda precisamente en la época de la conquista romana, cuando se va abriendo paso y se está configurando el orden político, económico y territorial de Iberia. No es de extrañar que las nuevas clases ibéricas que se abren a esta «italización» de la península necesiten transformar su viejo repertorio iconográfico con motivos de raigambre itálicohelenística. Pues resulta necesario recomponer el imaginario de la sociedad en crisis, crear un espacio con las nuevas fórmulas de la autorrepresentación del poder. Los animales perfectos, y especialmente los seres híbridos y los monstruos, son «buenos para pensar simbólicamente» ${ }^{44}$.

Algo parecido ocurre en la ya tantas veces mencionada pátera de plata sobredorada de Santisteban del Puerto, en Jaén, de época similar — difícil sin embargo de precisar - a las que estamos considerando en esta última serie ${ }^{45}$. El vaso de plata connota a su poseedor dentro del ambiente de los poderosos ibéricos cuya condición se expresa y exterioriza en las vajillas y adornos corporales argénteos (ritual, bebida, vestido...). El personaje que encarga y adquiere esta singular pátera asume un viejo pensamiento mítico local: el lobo monstruoso e infernal, rodeado de serpientes, que devuelve a través de su cuerpo la cabeza patética de un personaje masculino. A esta imagen predominante y única - la aparente sencillez de su mensaje arraigaría en la vieja tradición ibérica - incorpora una iconografía itálica nueva y variada, que requiere una secuencia narrativa de múltiples matizaciones: es decir, una aceptación de complejidad; una paideia en la familiaridad con el lenguaje mítico de tradición griega. El mensaje, envuelto en ropaje dionisíaco, se desarrolla en los dos frisos que rodean el umbo: el diminuto friso con erotes cazadores y una procesión de centauros y centauresas en la fiesta de un ban-

${ }^{44}$ D. Sperber, «Pourquoi les animaux parfaits, les hybrides et les monstres sont-ils bons à penser symboliquement?», L'Homme, XV.2, 1975, p. 21 ss.

${ }_{45}$ R. Olmos, Los Iberos y sus imágenes, 1999, cit. (n. 11), n. ${ }^{\circ} 89.1$, con bibl. 
quete dionisíaco. Este ejemplo ofrece un curioso cruce de fórmulas y de estilos entre el helenismo itálico y la tradición ibérica del lobo cuyas entrañas sirven como vehículo hacia el más allá. Una vez más y de forma consciente, el ibero incorpora a su repertorio escatológico el lenguaje de moda helenístico que el prestigio difunde entre la nueva sociedad de la Hispania republicana. No renuncia el aristócrata ibero a la apropiación de este lenguaje diferente que le permite acceder a estos nuevos privilegios más allá de la muerte.

Este mundo ibérico tardío del aristócrata local está lleno de alusiones míticas grecoitálicas que reelaboran la tradición heredada y la enriquecen. La plata - y en menor medida el oro- son un vehículo especial en esta renovada apertura al gusto mediterráneo. Las formas de los vasos de bebida nos permiten hablar de una verdadera vajilla iberohelenística de inspiración itálica. Pero esta corriente nueva se manifiesta, sobre todo, en la iconografía: la Victoria libando con pátera es el motivo de la pareja de pendientes de oro, hoy desaparecidos, del tesoro de Santiago de la Espada (Jaén) ${ }^{46}$. Su rostro, enmarcado por trenzas, es ibérico, como los de la cerámica de La Alcudia de Elche o de algunos exvotos. Un ave la acompaña, viejo signo de las divinidades femeninas en el Mediterráneo y en Iberia. Pero la diosa sostiene una pátera y liba, un gesto nuevo que asume también, por influjo itálico, algún exvoto de la acrópolis de Sagunto ${ }^{47}$. Y el manto de Nike se abre e infla por el viento del descenso. Hablamos de un gesto nuevo, la libación, y de una Victoria, que irrumpe con énfasis. ¿Acaso no resultó grata a Metelo aquella extraordinaria escenografía en Córdoba, cuando «tomó asiento, vestido de vencedor, en un comedor transformado en templo, perfumado con incienso, de cuya bóveda deslizóse, con teatral estrépito, una Victoria para ceñirle una corona» ${ }^{48}$. Nos precisa Plutarco: eran Victorias articuladas, movidas por máquinas, las que le ofrecieron desde lo alto trofeos de oro y coronas mientras que coros de niños y mujeres cantaban himnos de victo-

${ }^{46}$ Gérard Nicolini, Les Ibères. Art et civilisation. Ed. Fayard, París 1973, fig. 114; Klaus Raddatz, Die Schatzfunde der Iberischen Halbinsel vom Ende des dritten bis zur Mitte des ersten Jahrhunderts vor Chr. Geb. Madrider Forschungen, n. ${ }^{\circ}$ V. Berlín, 1969, lám. 57. En p. 53, Raddatz propone para este tesoro una fecha entre el 105 y 90/80 a. C. basándose en la comparación tipológica con otros tesoros mejor fechados por monedas. Los pendientes podrían ser anteriores.

${ }^{47} \mathrm{Cf}$. Michael Blech, «Republikanische Bronzestatuetten aus Sagunt»,en: Homenatge a A. Chabret 1888-1988. Valencia, 1989, pp. 43-91.

${ }^{48}$ Cf. Adolf Schulten, Sertorio, Barcelona, 1949, p. 164 y n. 586, de quien tomamos la cita entrecomillada. Cf. Plutarco, Sertorio, 22, 3. ria en alabanza de Metelo. Al igual que esos coros de edad y de género, las Victorias de los pendientes de oro pertenecen a esta perspectiva ibérica ante el fasto romano. La imagen ibérica se refleja también, indirectamente, desde la mirada de la referencia histórica.

El poder se alía con la naturaleza en las fíbulas del cazador, como la de Chiclana de Segura, en Jaén, o la de Los Almadenes de Pozo Blanco, en Córdoba ${ }^{49}$. El auriga del sol surge en su carro guiado por los prótomos equinos que nacen del horizonte para anunciar y propiciar la caza del noble, a caballo, hipercaracterizado como guerrero y acompañado de sus perros que merodean a la presa, el jabalí salvaje. El tiempo mítico y el actual se funden en esta doble imagen, que es modelo y referencia del aristócrata. El surgimiento de la biga del sol, bien conocido de la cerámica calena, se asume en estas fíbulas ibéricas que las dota de viejo sentido: la exaltación simultánea del príncipe guerrero y su actividad de la caza, pues sólo el noble es mediador entre la naturaleza y el ámbito de los dioses ${ }^{50}$. El surgimiento del carro del sol despierta y fecunda la naturaleza, cuyo sacrificio y reordenación regulará el príncipe guerrero, que caza al amanecer. Las fíbulas del cazador resumen el microcosmos de este orden social sancionado por los dioses. Un gran vaso ibérico de La Alcudia de Elche, posiblemente del siglo II a. de C., asocia este surgimiento de la biga alada del sol -su auriga, masculino o femenino, se manifiesta en su frontalidad- a la fecundidad vegetal del lugar ${ }^{51}$ (fig. 19). La simbiosis de la iconografía mediterránea con la vieja representación ibérica de la barca del sol conduce al surgimiento de estos vasos de encargo, únicos, irrepetibles.

Todo ello sirve, de un modo u otro más o menos directo, para aproximarnos al vaso de Valencia. Pues esta representación pertenece a un ambiente histórico y mitológico en cierto modo similar. En primer lugar, observamos que desde la primera época de la presencia romana en Iberia, es decir, en los siglos II e inicios del i a. de C., surge una eclosión de nuevas imágenes míticas, especialmente en cerámica,

${ }^{49}$ R. Olmos Los Iberos y sus imágenes, 1999, cit. (n. 11), n. ${ }^{\circ} 56.2 .1$, con bibl. (Chiclana de Segura) y n. ${ }^{\circ} 83.10$ (fíbula de Los Almadenes de Pozo Blanco (?) o Cañete de las Torres (Córdoba). Cf. G. Nicolini, 1973, cit. (n. 46), p. 129, fig. 119.

${ }^{50}$ R. Olmos, «Hélios en Iberie. Note pour une recherche», en: Agathòs daímon. Mythes et cultes. Études d'iconographie en l'honneur de Lilly Kahil, Bulletin de Correspondance Hellénique, Suppl. 38, Paris, 2000, pp. 393401, espec. p. 399 ss.

${ }_{51}$ R. Olmos Los Iberos y sus imágenes, 1999, cit. (n. 11), n. 56.1 , con bibl. 


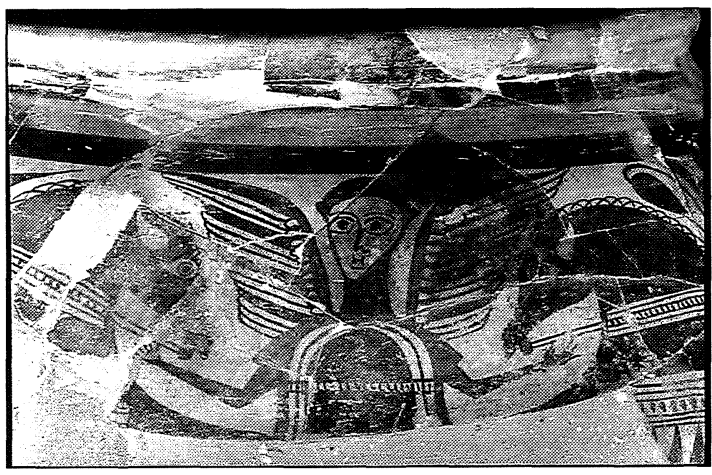

Fig. 19.-Divinidad alada en una biga de caballos alados, entre vegetación. Vaso cerámico de La Alcudia de Elche (Alicante). Museo monográfico de $\mathrm{La}$ Alcudia, Elche. Foto «Proyecto de iconografía ibérica», Instituto de Historia, CSIC.

pero también en monedas y en el vehículo selecto de los objetos de plata. Seguramente estamos ante manifestaciones sociales diversas, vinculadas a aristócratas en los ejemplos citados de oro y plata, o que afectan a un grupo social más amplio, a una comunidad que se define y muestra a sí misma, como es el caso de las monedas. El creciente desarrollo protourbano, impulsado por la anterior presencia colonial semita en la Bética y ahora por Roma, puede estimular el auge de mitos metamórficos y etiológicos de los orígenes de una comunidad. El mundo mítico con que en su poema épico Puni$c a$ el poeta imperial romano, Silio Itálico, recrea los nombres y genealogías fundacionales de diversos lugares de la Bética y de Hispania (por ejemplo, Nebryssa o Sagunto) puede no responder sólo a una pura invención poética de este autor sino a una erudición que nos lleva a este momento de eclosión mitológica que recorre la Hispania republicana ${ }^{52}$. Más adelante aludiremos de nuevo a esta idea.

Un ejemplo de esta búsqueda de los orígenes míticos puede ser el cálato o sombrero de copa con el labrador mítico de Alcorisa (Teruel) y su paralelo gemelo de Azaila (Teruel) (figs. 20 y 21) ${ }^{53}$. Este vaso singular reúne tres escenas que se relacionan íntimamente: una imagen de labranza, en el centro; a la izquierda, cuatro personajes afrontados en torno

52 Nebryssa: Punica, III, v. 393: «ac Nebrissa dei Nysaeis conscia thyrsis»; Sagunto/Zakynthos: Punica, II, vv. 273 ss.

${ }^{53}$ Ricardo Olmos, «Metáforas de la eclosión y del cultivo. Imaginarios de la agricultura en época ibérica», $A E s p A$, 69,1996 , pp. 3-16; véase una lectura en gran medida divergente de la mía, en Carmen Aranegui, «Personaje con arado en la cerámica ibérica (ss. II-I a. de C.). Del mito al rito», en: Mélanges Cl. Domergue, Pallas, 50, 1999, pp. 109-120. Finalmente, R. Olmos Los Iberos y sus imágenes, 1999, cit. (n. $11)$, n. $^{\circ} 77.1$. a una gran flor o árbol de la fecundidad, cuyo crecimiento propician con su gran mano elevada y, acaso, con sus pies en movimiento ${ }^{54}$; a la derecha, un motivo de caza inminente. Limitan las escenas columnas de aves afrontadas a grandes brotes vegetales. El labrador, con vara en su diestra, gobierna con la izquierda el timón de un arado con una yunta de bueyes. Es el antepasado, el inventor del arado, el primer sometedor de los bueyes al yugo, héroe benefactor de los hombres. $\mathrm{O}$, tal vez, el fundador del lugar que con la yunta traza las lindes, los límites del territorio. Grandes aves le rodean. Llama la atención el tamaño e importancia de éstas, superior al de los bueyes y al humano. Su presencia se incorpora al ritual del crecimiento. Sus picos pueden fecundar también la tierra y, al herirla, provocar el crecimiento de las semillas. Se vinculan a la fructificación del suelo. Toda la naturaleza interviene en el acto sagrado, incluído el gran búho que mira fijamente, de frente. No se expresa el dominio autónomo del hombre sobre la naturaleza-objeto sino el diálogo del labrador con ella, su participación en el crecimiento junto a los animales y los genios propiciadores.

La escena se complementa con una escena de caza. Apostados tras una tupida y fecunda vegetación, dos cazadores míticos aguardan a sendos jabalíes emboscados, prestos a atacar. Una jauría de perros se abalanza tras la pareja de jabalíes. Las imágenes del vaso constituyen un ciclo, un conjunto, en el que el héroe participa como mediador del devenir del cosmos. Agricultura y caza, el cultivo de la vida y la regulación ordenada de la muerte le son encomendadas al héroe mítico como modelo e intermediario ritual. Este vaso adquiere su pleno sentido en el contexto de la habitación singular donde aparece. En este espacio se acumulan otros vasos de formas variadas, generalmente de bebida y decorados con escenas del mundo vegetal y animal ${ }^{55}$. Hay una profusión de formas ibéricas que imitan la diversidad de una vajilla itálica de época helenística: cántaros, jarras de tipo oinochoe, crateras adornadas, etc.

${ }^{54}$ Cf. el fragmento cerámico ibérico del Cerro de los Santos (Montealegre del Castillo, Albacete), con la parte inferior de dos personajes, dibujados a contorno, enfrentados a un motivo acabado en punta, probablemente un elemento floral (Museo de Albacete). Los pies de ambas figuras humanas, cuyas piernas se muestran en vivo movimiento, podrían golpear y herir el suelo, como en el ritual itálico del terpudiare («pellere ter pede terram», batir tres veces con el pie la tierra, para propiciar así el crecimiento de las plantas). Cf. Lucrecio, De Rerum Natura, V, 1402; Horacio, Carmina, III, $18,15-16$.

55 Cf. P. Atrián Jordán y M. Martínez, «Excavaciones en el poblado ibérico del Cabezo de la Guardia de Alcorisa», Teruel, 55-56, 1976, pp. 59-65. 


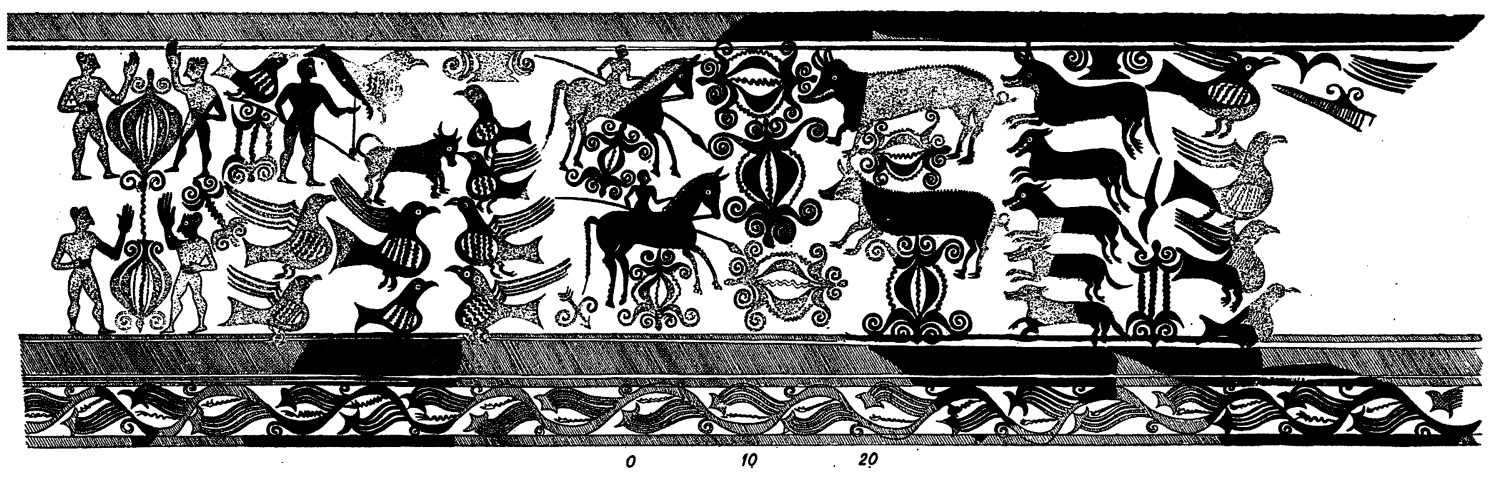

Fig. 20.-Desarrollo y reconstrucción de la escena del cálato de Azaila (Teruel), según Juan Cabré, Cerámica de Azaila. C.V.H., 1944, fig. 46.

De esta escena, decimos, existe un paralelo muy preciso en el poblado vecino de Azaila: un mismo artesano ha realizado ambos vasos ${ }^{56}$ (fig. 20). Quienes los encargaran en aquel ambiente iberorromano del valle de Ebro pudieron desear exaltar el prestigio de las actividades agrarias y cinegéticas mediante la recreación de sus nobles orígenes, asociando creencias arraigadas de antiguo a un pensamiento de evergetismo propio de la época. Sólo en el tiempo del mito se justifica la representación del trabajo, actividad innoble que conlleva esfuerzo, bánausos. La esfera ideal, no la cotidiana, lo justifica. Parece sintómatico que la imagen del labrador se introduzca en un momento - finales del siglo II y siglo i a. de C.- en que Roma busca provisiones de trigo fuera de Italia (en España, en Sicilia, en Africa) ${ }^{57}$. Hispania se convertirá en uno de los graneros de Roma. La emigración itálica hacia la península busca el cultivo de tierras nuevas. La creación de las colonias tendrá como uno de sus extendidos símbolos al labrador mítico, «bonum agricolam bonumque colonum». La imagen de este vaso, desconocida hasta ese momento, su repetición en zonas tan próximas, como son el poblado de Azaila y esta finca o casa señorial de Alcorisa, deben ponerse en relación con una forma de integración de la tradición aristocrática ibérica con la nueva política impulsada por los colonos de Roma. La imagen precede, individualmente, a las tempranas acuñaciones imperiales de las nuevas colonias -Emerita Augusta, Caesar Augusta, hacia 25 a. C.- con la representación del labrador-sacerdote fijando las lindes del pomerium, ya al modo

56 J. Cabré, Cerámica de Azaila, 1944, cit. (n. 6), pp. 6566, fig. 48.1; fig. 49.

57 Claude Nicolet, Rome et la conquête du monde méditerranéen, Nouvelle Clio, Paris, 1978, (reimpr. 1997), pp. 103 ss.; id., Les Gracques. Crise agraire et révolution à Rome, Gallimard/Julliard, Paris, 1990, pp. 93-94. propiamente romano ${ }^{58}$. La imagen del vaso, de uso individual y aristocrático, extiende en las monedas su mensaje a los colonos del lugar, la ciudad. Aprender a llevar el yugo es signo de romanización ${ }^{59}$

Sin embargo, ninguno de estos vasos citados nos asocia el tema de la naturaleza mítica con la posible ideología hoplítica de guerreros que se muestran

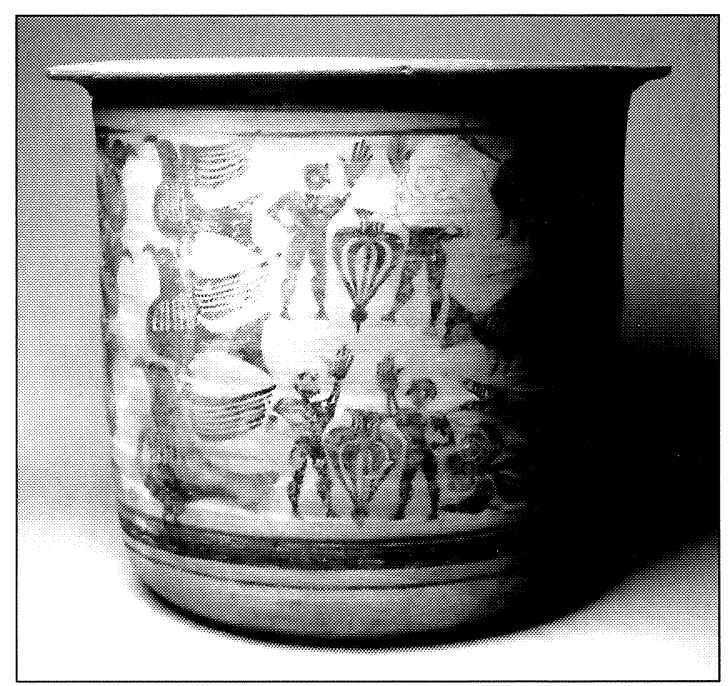

Fig. 21.-Cálato del poblado de Alcorisa (Teruel). Personajes, al modo de genii loci, afrontados a grandes brotes florales. Para el motivo, cf. la figura anterior, de Azaila, a la izquierda. Foto cortesía del Ministerio de Educación, Cultura y Deporte, Madrid.

${ }_{58} \mathrm{M} .{ }^{a}$ Paz García-Bellido, «La moneda y la guerra», en: J. A. García Castro y V. Antona (dirs.) (1997), La guerra en la Antigüedad. Una aproximación al origen de los ejércitos en Hispania. Comunidad de Madrid. Madrid, 1997, pp. 320321 .

59 No así el cántabro, «indoctum iuga ferre nostra», dice el poeta Horacio Odas, 2,6,2. «Iuga ferre» debe entenderse aquí en su sentido metafórico (el cántabro rebelde, que no se somete al yugo del vencedor) más que en su sentido real (no haber aprendido a -indoctum - llevar las yuntas del arado). 


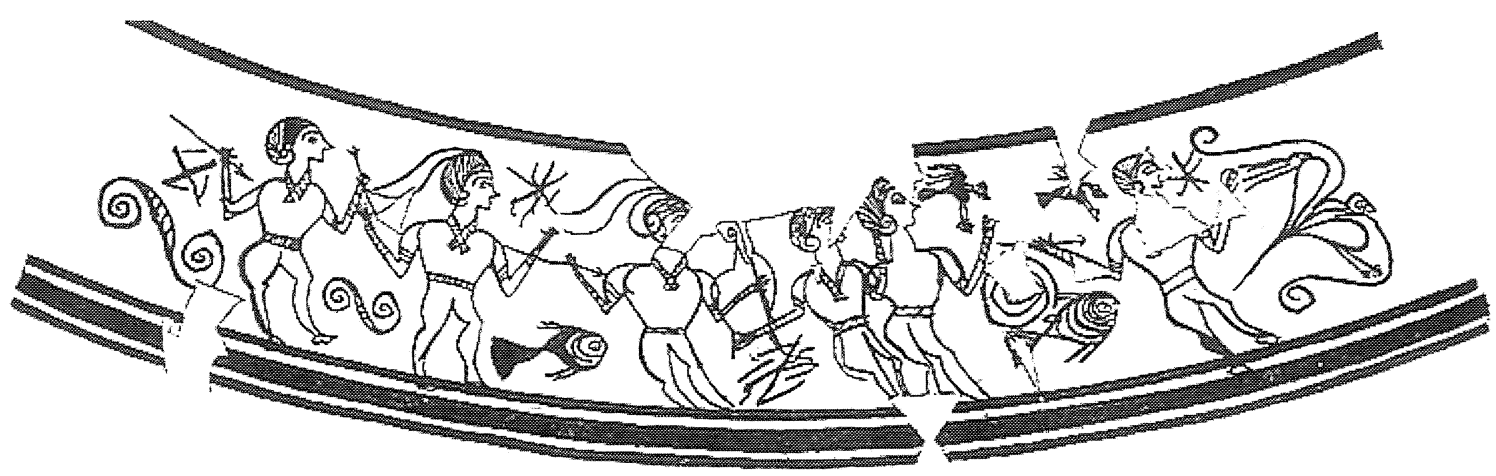

Fig. 22.-Desarrollo de la escena de un ánfora del poblado de San Miguel de Liria (Valencia), con procesión de infantes y animales hacia la derecha, donde tiene lugar una metamorfosis. Cf. detalles en figuras 23-24. Museo de Prehistoria de Valencia. Dibujo según Ballester et alii, Corpus Vasorum Hispanorum. Cerámica del Cerro de San Miguel de Liria. C.S.I.C. Madrid, 1954.

armados, en condición de iguales, y que asisten a una metamorfosis, a un hecho milagroso, un thauma o mirabilium. Esta asociación es la que nos ofrece un anterior vaso singular de Liria sobre el que, creo, no se ha llamado todavía suficientemente la atención.

Me refiero a una gran tinaja con dos asas verticales de triple nervadura (la central trenzada) que enmarcan el campo decorativo ${ }^{60}$ (figs. 22-25). Un friso de guerreros marcha hacia la derecha, la mayoría con una jabalina en su diestra, en actitud de ataque. Visten túnica ceñida por cinturón y dos de ellos ostentan casco con largas crines. Los pequeños tirantes rituales se cruzan sobre el cuello: caracterizan el momento singular de una fiesta (fig. 23). Es relevante el ritmo de las figuras en el espacio. El varón que precede al grupo, separado de los demás, inclina hacia atrás el cuerpo y eleva su mano izquierda en un gesto de asombro o de propiciación (fig. 24). Dos peces y dos aves le acompañan en la misma dirección: expresan la fidelidad y solidaridad del cosmos, la sympátheia o concordia de intereses entre los linajes de los animales y los hombres; son imagen teleológica de una naturaleza armónica y participativa. He aquí la explicación a esta inquietud común: en la zona de las asas, ante los hombres y ante los animales que acuden presurosos, una gran flor se abre y se transforma súbitamente en un ave de la que se señala la cabeza y las patas: el detalle fotográfico hace patente y magnifica algo más escondido en el ánfora (fig. 25). En la cerámica ibérica este espacio o zona del vaso junto a las asas es un lugar propicio para las metamorfosis. Los demás personajes se acumulan a medida que se acercan al que les precede. Hay una relación entre los guerre-

${ }^{60}$ Helena Bonet, 1995, cit. (n. 8), pp. 168-178, fig. 83; Ricardo Olmos, 1998 , cit. (n. 8), p. 151 , figs. 7 y 8 . ros vestidos con atuendos sacros y este surgimiento singular que atrae por igual a los hombres y a la Naturaleza zoomorfa y vegetal. Estamos ante un desfile o escena ritual, reservado a un grupo de guerreros, en que interviene el elemento mágico y singular de la transformación. No ha de extrañarnos la existencia de estos mirabilia o prodigios ante hombres notables, que se aglutinan en torno al hecho
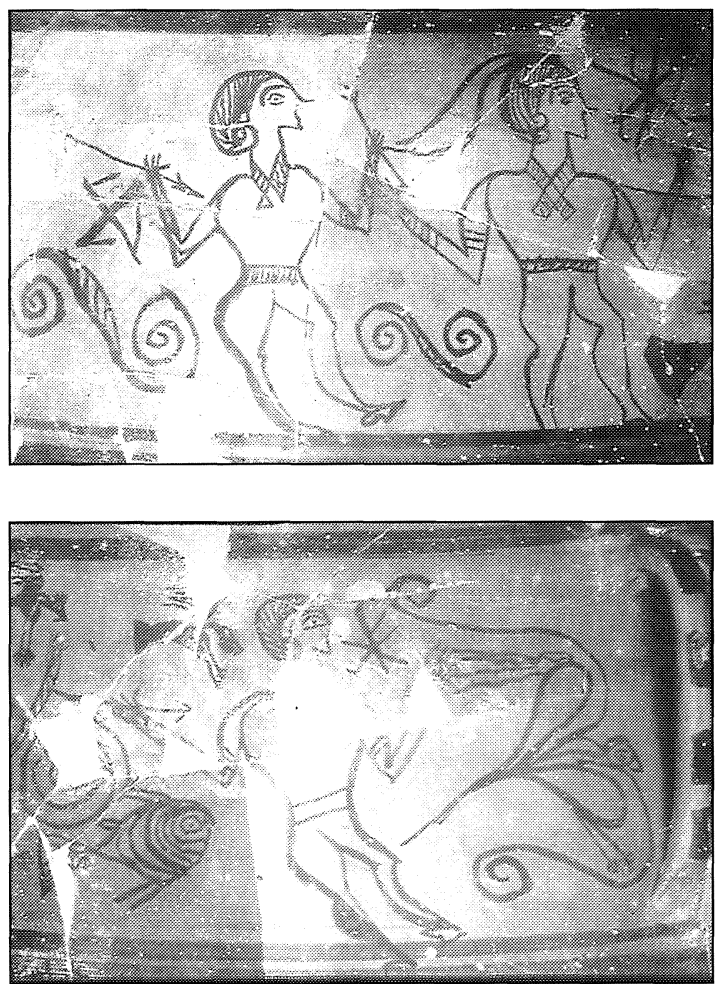

Figs. 23 y 24.-Detalles del ánfora del poblado de San Miguel de Liria (Valencia), con procesión de infantes y animales. Cf. figs. 21 y 24. Fotos según Helena Bonet, El Tossal de Sant Miquel de Llíria, Valencia, 1995. 


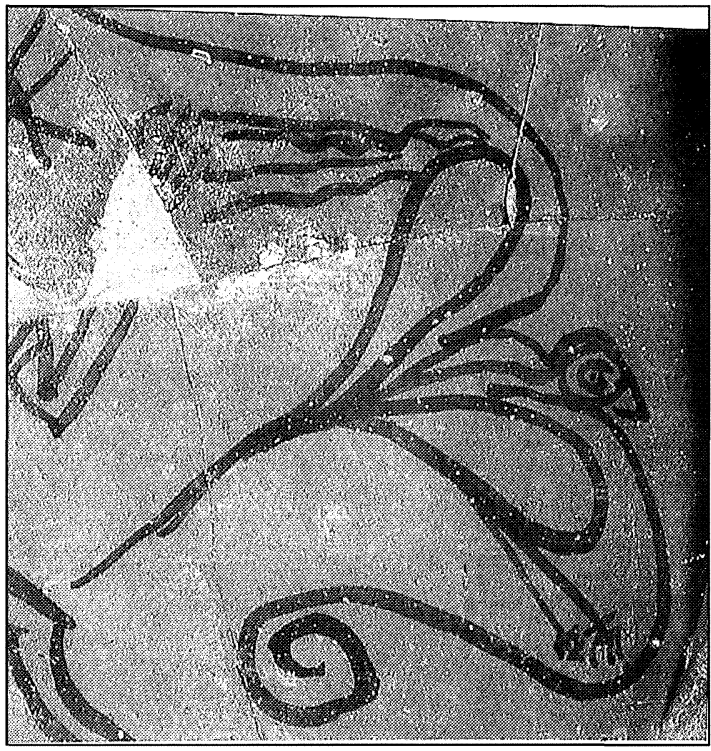

Fig. 25.-Escena de metamorfosis: ave surgiendo de un brote floral. Detalle del ánfora del poblado de San Miguel de Liria (Valencia), cf. figs. 20-23. Foto según Helena Bonet, $E l$ Tossal de Sant Miquel de Llíria, Valencia, 1995.

milagroso y excepcional de la naturaleza para admirarla ${ }^{61}$. Ni tampoco puede ya desconcertarnos la asociación entre poder guerrero y metamorfosis, un tema recurrente en la iconografía ibérica. Recordemos los vasos de eclosión de la vegetación maravillosa y sobreabundante, metáfora del poder y de la fecundidad del lugar, que tan bien conocemos por la cerámica de La Alcudia de Elche. El tema es, obsesivamente, la naturaleza vegetal que surge automática, espontáneamente - sponte sua- y en abundancia, criadora sin tasa, satis. Pero no es la naturaleza lo que les interesa sino la historia, la vida humana, «cuando los tiempos de ahora con otros tiempos coteja de antaño» del verso de Lucrecio ${ }^{62}$. Lo que aquella tierra mágica producía por sí sola colmaba a los hombres, sus necesidades. El ejemplar de Valencia encuentra abono en esta tradición de vasos ibéricos de metamorfosis y de los orígenes en que el hombre no es sino excrecencia de una na-

${ }^{61}$ La imagen entraña la admiración de los meliores ante el cosmos, tan arraigada en el pensamiento estoico de época helenística, como expresa aquel fragmento, tan reiteradamente aludido por el filósofo Karl Löwith, que dice así: «Llegará un tiempo en que por hastío los hombres dejen de maravillarse ante el cosmos y de considerarlo digno de adoración. Este bien supremo en su totalidad, lo mejor que ha existido, existe y se podrá ver jamás, correrá el peligro». $\mathrm{Cf}$. Karl Löwith, Conocimiento, fe y escepticismo (Wissen, Glauben und Skepsis) Göttingen, 1958 (2. ${ }^{\mathrm{a}}$ ed.). Es citado en: J. Habermas, «Karl Löwith. Repliegue histórico frente a la conciencia histórica», Perfiles filosófico-políticos; Madrid (Taurus), 1975, pp. 175-194, especialmente, p. 177. turaleza expresada en su totalidad pero siempre en relación con la historia humana del territorio.

En la aproximación que aquí presentamos a la insólita escena del nuevo vaso, he aquí nuestra propuesta interpretativa.

Recordemos, primero, sumariamente, la historia. Un primer asentamiento urbano había sido fundado en Valencia en el 138 a. de C. por el cónsul romano Decimus Iunius Brutus para acoger a los veteranos que habían guerreado con Viriato ${ }^{63}$, según refiere expresamente el tardío epítome de Tito Livio e indirectamente, Apiano y Diodoro Sículo ${ }^{64}$. Hubo adsignatio de tierras: Iunius Brutus les entregó «agros et oppidum». Apenas unas seis décadas después, Valencia fue destruida durante las guerras sertorianas por el ejército de Pompeyo tras la batalla junto al río Turia del año 75 a. de C. ${ }^{65}$. Allí mueren el general sertoriano Gayo Herennio y diez mil hombres ${ }^{66}$. En el período anterior a la masacre de Pompeyo, época de la reconstrucción política de la ciudad y de remodelación de los grupos sociales con Sertorio, se sitúa el vaso. Éste coincide con el momento en que el lugar, constituido probablemente como colonia civium Romanorum, puede recibir el nombre de Valentia, voz que proclama la fortaleza y potencia de sus habitantes ${ }^{67}$. Proponemos que estamos ante un vaso de encargo que cuenta los orígenes míticos del lugar, fecundo, vigoroso e insólito.

${ }^{62}$ De Rerum Natura, II, 1166 (traducción de A. García Calvo).

63 María José Pena, «Consideraciones sobre el estatuto jurídico de Valentia», Papeles del Laboratorio de Arqueología de Valencia, 22, 1988, pp. 303-329. Para un análisis histórico general de Sertorio desde las fuentes históricas, cf. Félix García Morá, Un episodio de la Hispania republicana: la guerra de Sertorio, Universidad de Granada, Granada, 1991; idem, Quinto Sertorio. Roma, Universidad de Granada, Granada, 1991.

${ }_{64} \mathrm{Cf}$. Livio, Epitome, 55: «Iunius Brutus cos. iis, qui sub Viriatho militauerunt, agros et oppidum dedit, quod uocatum est Valentia»; Apiano, Iberia, 6,75; Diodoro Sículo, 33,3.

65 A. Ribera, 1995, cit. (n. 3), pp. 19 ss.

66 Plutarco, Pompeyo 18: «Venciendo Pompeyo en el cerco de Valencia, donde dió muerte a diez mil hombres». El adjetivo «myríous» puede tener el sentido específico del numeral diez mil o, más probablemente, el más genérico de «innumerables, incontables», cifra para designar, de forma imprecisa, una matanza desorbitada.

67 Alfonso García-Gallo, «La ciudad de Valencia y su condición jurídica en época romana», Anuario de Historia del Derecho Español, 48, 1978, pp. 549-575, espec. p. 561 (sobre la Valencia de Sertorio). Propone García-Gallo que es Sertorio quien constituye la nueva ciudad como colonia $\mathrm{ci}$ vium Romanorum y quien pudo otorgar el nuevo nombre parlante de Valentia. Es poco verosímil, dice, que este nombre lo recibiera anteriormente, con la primera creación de Iunio Bruto, destinada, de hecho, a los soldados derrotados en las guerras con Viriato. El Epítome de Livio no lo afirma: la expresión «quod vocatum est Valentia» no implica, efectivamente, que la denominación proceda de esa primera fundación. El momento queda indeterminado. 
El mundo ibérico mantiene hasta época muy avanzada la producción de talleres que pintan por encargo escenas irrepetibles, que se adaptan, en la continua invención de temas, a la demanda y exigencias de sus clientes, las familias y aristócratas que detentan el poder en la nueva sociedad ibérica. Conocemos esta tradición en algunos ejemplos de Liria - un siglo antes- y del valle del Ebro (de un momento coetáneo e incluso posterior a nuestro ejemplo). La tradición artesanal del vaso pintado con algunas de sus viejas fórmulas transformadas se extendería ahora, a inicios del siglo I a. de C., a las demandas de los veteres sertorianos que ocupan el nuevo asentamiento de Valentia.

Se relata un prodigium que relaciona las armas con un monstruo de extraordinario tamaño, ser devorador o engendrador, o ambas cosas a la vez. Podría contarse la historia de los originarios seres míticos anteriores a la fundación de la ciudad, espacio que comparten animales, monstruos y, aparentemente, un ser humano en un momento de tránsito, que es devorado o, mejor, surge a través de las fauces del ketos. Es notable la caracterización isonómica de los personajes híbridos en gestos y en armas: la insólita jabalina-arpón y el casco de piel los iguala. También su actitud y gestualidad. El monstruo imposible, ketos y cuadrúpedo a la vez, pertenece a ese mundo liminal en que se encuentran la tierra y el mar. El puerto de la Valentia sertoriana donde apareció el vaso puede quedar aludido en ese espacio híbrido que llena la figura del monstruo ${ }^{68}$. Tras el oppidum, los agri.

La vinculación entre nacimiento metamórfico del ser inaudito y los orígenes del lugar es lugar común en los relatos helenísticos de fundación: cosmología y etiología confluyen en la narración de los orígenes históricos de los lugares, son su expresión geográfica. La apropiación histórica del lugar se realiza a través del thauma o portentum, el suceso milagroso mítico. Tal es la principal función cognitiva y explicativa de numerosas metamorfosis helenísticas ${ }^{69}$. Por ello, el paralelo funcional más próximo a nuestra escena lo hallaremos no ya en la cerámica sino - a pesar de su función específicaen las monedas. La famosa serie de la acuñación ampuritana con la metamorfosis del caballo Pegaso, siempre tan mal interpretada, es un caso muy próximo al nuestro ${ }^{70}$ (fig. 26). Tras la segunda guerra

${ }^{68}$ Así me lo ha sugerido oralmente la Dra. Isabel Izquierdo.

69 K. Sara Myers, Ovid's Causes: Cosmogony and Aetiology in the Metamorphoses; Univ. Michigan Press, 1994, pp. 56-57, etc.

${ }^{70}$ Ll. Villaronga, 1994, cit. (n. 25), p. 22 ss. «Después del año 218 a. C.-Pegaso con la cabeza modificada en Cabiro.»

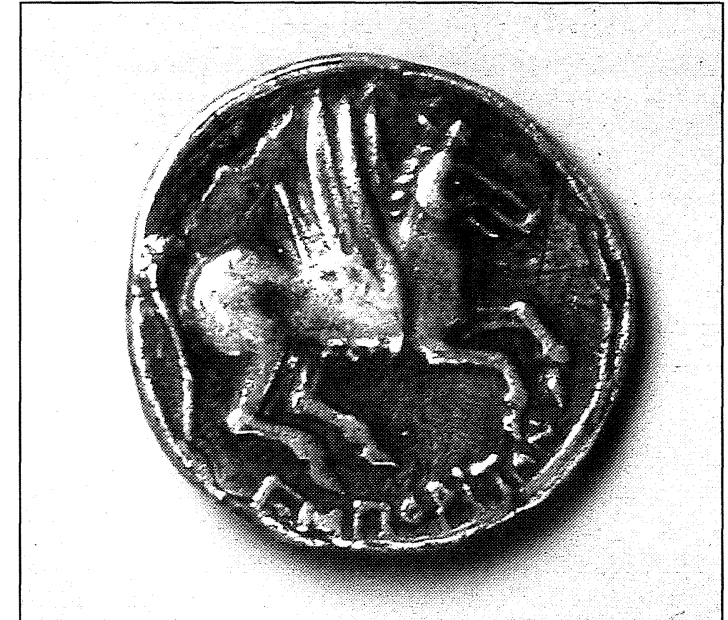

Fig. 26.-Dracma ampuritana. Reverso con el caballo alado y un niño en posición fetal configurando la cabeza del animal. Museo Arqueológico Nacional. Foto cortesía del Ministerio de Educación, Cultura y Deporte, Madrid.

púnica en Ampurias resulta necesario reinventar los orígenes del lugar, borrar cualquier ambigüedad de su anterior iconografía mítica que pudiera interpretarse desde el mito púnico: el caballo parado, la Tanit/Deméter, tal vez el mismo Pegaso. Y para ello se acude a una metamorfosis: la cabeza del caballo alado Pegaso, que desde antiguo aludía a la fuente mítica - pegé- del lugar que da de beber a la comunidad ${ }^{71}$, se transforma en la figurita de un pequeño niño desnudo, con las manos estiradas agarrando los pies, en posición fetal. Tal vez la renovación de la ciudad, su destino futuro, se ligaría al nacimiento milagroso de un niño surgido del mítico Pegaso del lugar. La nueva imagen - un ser inhabitual, insólito- no resulta evidente a una primera observación. La desvía el engaño previo de los sentidos; exige la predisposición y favor del espectador que la completa. Entraña un juego de percepción, un aínigma, es decir, un signo cuyo mensaje secreto hay que descifrar. También en el monstruo de Valencia se esconde un enigma, una figura imposible e híbrida que, como en Ampurias, contiene la historia originaria y fundacional del lugar. Del ímpetu de ambos monstruos vigorosos nacerá una singular estirpe humana: un niño en Ampurias (infante del tiempo nuevo, de la renovatio); monstruos o personajes en que se apuntan ya los atributos y gestos de la cultura humana - el manejo de las armas-en Valentia.

Los mitos surgen por encargo o por necesidad de las comunidades cívicas para las que trabajan cera-

71 R. Olmos, «Usos de la moneda en la Hispania prerromana y problemas de lectura iconográfica», 1995, cit. (n. 24), pp. 46-47. 
mistas y poetas. Los hombres se revelan philómythoi, amantes de mitos, éstos son propedéutica para comprender la realidad ${ }^{72}$. La creación de relatos míticos favorece el fundamento político de la vida humana. No es casual que en la época de nuestro vaso, a inicios del siglo I a. de C., veamos multiplicarse, tanto en imágenes como en referencias textuales, algunos posibles mitos de fundación urbana en la temprana Hispania romanizada: en Iberia se muestra una ciudad llamada Odysseia, entre otras mil huellas de la peregrinación de aquel héroe homérico. Esta referencia, entre otras muchas, la recoge Estrabón del filósofo estoico Asclepíades de Mirlea, quien, aproximadamente por los mismos años de nuestro vaso, enseñaba «tà grammatiká» en la Turdetania al tiempo que publicaba una periégesis o descripción de los pueblos que la ocupaban ${ }^{73}$. Hemos aludido a la posible historicidad de algunos pasajes del libro III de Silio Itálico, quien acude — por ejemplo, en su descripción del Heracleion gaditano- a fuentes de autores helenísticos como Artemidoro y Posidonio ${ }^{74}$.

Pero recordemos además cómo existe en esta época una receptividad especial a todo tipo de mirabilia, de apariciones monstruosas, de signos extraordinarios y premonitorios asociados a veces con las armas, como el sueño anunciador de Aníbal tras partir con su ejército desde Carthago Nova hacia el Ebro, junto a la ciudad de Onusa, cuyo campo devasta una descomunal serpiente ${ }^{75}$. O como la singular historia que refiere Pausanias en relación con Gades, que se vincula - como en nuestro vaso- a la identidad de un lugar ${ }^{76}$. Un viajero llegado de Grecia, Cleón de Magnesia, de biografía imprecisa, es causalmente testigo de un thauma de este.tipo. Sobre la playa de Cádiz ha visto arder un andra thalássion o monstruo marino semihumano y gigantesco, con ocasión de un ritual, secreto y reservado, al que sólo está permitida la asistencia de los ciudadanos de la urbe semita. En esta fiesta de los sympolitai, a la que no pueden asistir ni extranjeros ni esclavos, se quema en la playa a una divinidad in effigie ${ }^{77}$. Es una divinidad marina,

${ }^{72}$ Claude Calame, Mythe et histoire dans l'Antiquité grecque, Lausanne (Payot), 1996, p. 165.

${ }_{73}$ Estrabón, Geografía, III, 4, 3.

${ }^{74}$ Finalmente, R. Olmos, «El Hércules gaditano en la geografía mítica del Extremo Occidente», en: R. Rolle-K. Schmidt (Eds.), Archäologische Studien in Kontaktzonen der antiken Welt. Veröffentlichungen der Joachim Jungius-Gesellschaft der Wissenschaften, Hamburg, 87, 1999, pp. 517-529, espec. p. 517, n. 4 con bibl.

75 Tito Livio, 21, 22: «una serpiente devoradora, de tamaño sobrenatural, mira magnitudine, lo seguía; a aquél le estaba vedado mirarla. No debió jamás volver la vista atrás».

${ }^{76}$ Periégesis, X,4,6.

77 ¿Se trata de una evocación de la ekpýrosis o combustión final del héroe Melcart? mítica, monstruosa. El texto sirve a Pausanias para certificar la existencia de estos thaúmata o mirabilia basándose en el testimonio de autoridad del citado viajero magnesio que asiste furtivamente al ritual en Cádiz. A nosotros nos interesa la aplicación local de esta historia. El citado vaso de Liria, con los varones asistiendo a un thauma o hecho milagroso apunta posiblemente a una historia fundacional de este tipo que aglutina a los iguales, los hómoioi de una ciudad, aquí el oppidum de Liria y su territorio.

El mismo Sertorio, un eques sabino oriundo de Nursia, ha fomentado como parte de su política en Hispania el desarrollo de mitos e instituciones locales que envuelven su caudillaje en un aura epifánica, sagrada, milagrosa ${ }^{78}$. Al mismo tiempo, Sertorio se propuso enseñar a los iberos el uso de las túnicas y clámides floridas, así como el empleo de armas y tácticas al modo romano. Todo ello ha de alejarlos de su aspecto salvaje ${ }^{79}$. En el marco de esta paideia sertoriana puede situarse la invención de ciertos mitos. El ambiente político que vive Hispania en estos años del inicio del siglo I a. de C. propicia en los notables el clima de expectación y efervescencia religiosa, la manifestación de prodigios que se asocian a los hechos militares. La historia muestra aquí su mejor modelo de tiempo aleatorio, su faz más compleja, abierta a la «irrupción imprevisible de la novedad» ${ }^{80}$. Nuestro vaso es un ejemplo de esta novedad.

Sigamos con ese mundo que se vislumbra aún imprecisamente en Sertorio. Evoquemos el famoso episodio de la cierva blanca cuya aparición traía buen augurio y fortuna a las campañas del caudillo romano y que él utilizaba como forma de relación religiosa con unos iberos envueltos en la fuerza supersticiosa o deisidaimonía ${ }^{81}$. Él será varón guiado por un demon y querido de los dioses, como un rey ${ }^{82}$. La historia de la cierva que nos refiere Plutarco responde bien a la integración y uso que realiza Sertorio no sólo de las creencias sino también de las instituciones indígenas ${ }^{83}$. Nos cuenta aquí Plutarco que un joven ibero había cazado a la carrera una cierva fugitiva que acababa de parir (un élaphos neotókos), asombrado por la blancura resplandeciente de su piel. La referencia, ciertamente escue-

78 Domingo Plácido, «Sertorio», Studia Historica. Historia Antigua, VII, 1989, pp. 97-104, especialmente p. 99: Sertorio fomentará los caracteres de una realeza apoyada en la inspiración religiosa.

${ }_{79}$ Plutarco, Sertorio, 14.1: manikón kaì theriôdes aphairôn.

${ }^{80}$ Cf. St. Mosès, El Ángel de la historia, Madrid, 1997, p. 23.

Plutarco, Sertorio, 11.6

82 Plutarco, Sertorio, 20.5. Cf. D. Plácido, 1989, cit. (n. 78), p. 99.

83 Plutarco, Sertorio, 11,2. 
ta, puede esconder un rito iniciático de caza por parte de jóvenes iberos, muestra de excelencia y paideia (recordemos que una de las preocupaciones de Sertorio es la paideia de los adolescentes locales en la antigua ciudad de Osca, verdaderos rehenes que constituyen una singular forma de dependencia dentro de la formación de las clientelas en las que el caudillo basa su política) ${ }^{84}$.

En cuanto a la caza del ciervo evoquemos la imagen - por lo demás tan singular- del vaso ibérico llamado Cazurro por su primer propietario, vaso que se dice fue hallado en la necrópolis del Portitxol de Ampurias: dos jóvenes corren semidesnudos para dar caza a ciervos en medio de un paisaje agreste apenas insinuado ${ }^{85}$ (fig. 27). Otros vasos del área ibérica del valle del Ebro o de la misma Liria, como el llamado vaso de la Rueda, repiten el motivo de la caza de ciervos entre las actividades aristocráticas de los iberos ${ }^{86}$.

Alguna escena, como en un cálato de Azuara (Zaragoza), se detiene incluso en el momento dramático en que la cierva herida, atacada por lobos, encuentra la muerte mientras amamanta a su cría ${ }^{87}$. Por cierto, esta expresión de la naturaleza - la asociación de la muerte que sobreviene al ser fecundo en el curso cíclico de la génesis y la phthorá, generación y destrucción que conlleva y exige el retorno continuo a una nueva vida- es una característica del pensamiento mitológico ibérico, tal como lo muestran sus imágenes.

En Plutarco, la cierva de Sertorio es fecunda, acaba de parir y la fecundidad animal se transmite a la buena fortuna del caudillo romano: la cierva es para Sertorio regalo de Ártemis y la convierte en signo epifánico. Como el vehículo de los sueños, del que se sirve el caudillo romano, ella es anunciadora de buenas noticias. Tras la dudosa batalla del Sucro, el hallazgo de la cierva, que se había perdido, es interpretado por Sertorio como señal de la renovada amistad de los dioses. La gestualidad del animal - salta alegremente hacia su amo, pone su cabeza sobre su regazo, le lame su mano ${ }^{88}$ - es

${ }^{84}$ Plutarco, Sertorio, 14.3. Cf. D. Plácido, 1989, cit. (n. 78).

8.5 Les Ibères, París-Barcelona-Bonn, 1997-1998, p. 256, n. ${ }^{\circ}$ 61. R. Olmos, Los Iberos y sus imágenes, 1999, cit. (n. 11), n. ${ }^{\circ} 82.5$.

${ }_{86}$ R. Olmos, Los Iberos y sus imágenes, 1999, cit. (n. 11), n. 78.6 (Vaso de la Rueda). Otros ejemplos en R. Olmos, ibidem, n. ${ }^{\circ} 83.1$ y ss.

${ }_{87}$ Miguel Beltrán, Los iberos en Aragón. Caja de Ahorros de La Inmaculada de Aragón. Zaragoza, 1996, p. 144, fig. 132. R. Olmos, Los Iberos y sus imágenes, 1999, cit. (n. 11), n. ${ }^{\circ} 83.7$.

${ }^{88}$ Para el episodio del sueño y la cierva, cf. A. Schulten, 1949, cit. (n. 48), p. 149.

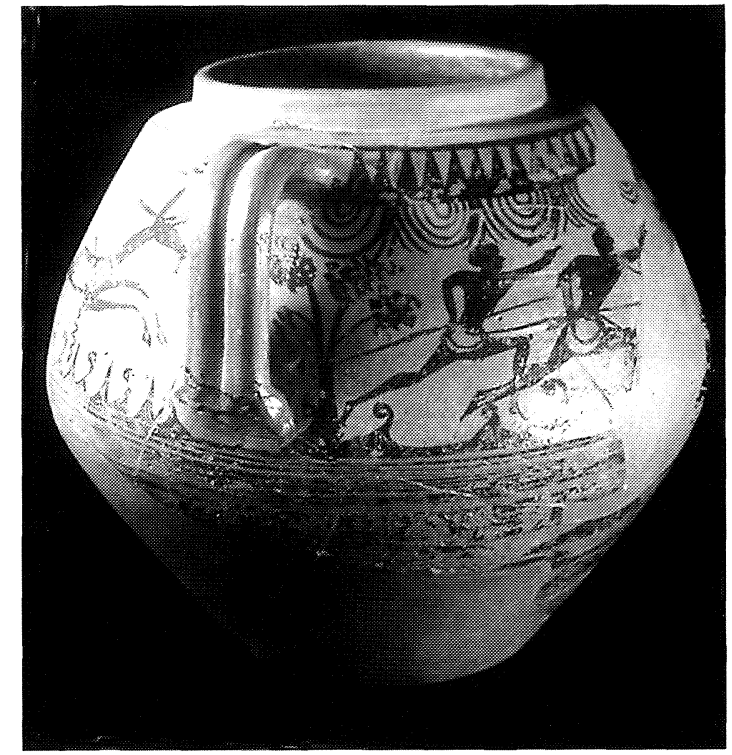

Fig. 27.-Jóvenes cazadores, corriendo tras unos ciervos. Vaso llamado «Cazurro», de Ampurias. Museo Nacional de Arqueología de Cataluña, Barcelona. Foto cortesía del Museo.

sympátheia, expresión de concordia de la naturaleza sagrada con el hombre: participa el animal con el éxito del príncipe. El detalle, que refiere Plutarco, no es trivial, meramente anecdótico. Por el contrario, el motivo entronca en la figuración ibérica de la época que acabamos de mencionar.

Es hora de volver al vaso llamado del «Ciclo de la Vida» de Valencia y resumir las conjeturas. El vaso, procedente de un contexto bien fechado y con esta escena única, nos plantea el problema de la relación de su iconografía con el ambiente sertoriano en que surge y con la colonia de Valentia. Estamos, creo, ante un vaso de encargo. El cliente debe pertenecer a la clase dominante provincial de Hispania, tal vez alguno de los homines novi que fomenta la política de Sertorio. Pueden ser los veteranos o veteres asentados en la nueva ciudad y que viven el proceso de integración y adaptación a la ciudadanía ${ }^{89}$. Son el tipo de clientes receptivos a los prodigia; clientes que, mediante una imagen legitimadora, buscan la alusión de un evento histórico con que recrear una representación mítica del lugar. Un lugar próximo al mar cuyo mismo nombre, Valentia, pregona la potencia de sus hombres; un lugar que se

${ }^{89}$ Cf. D. Plácido, 1989, cit. (n. 78), p. 102. Cf. anteriormente, Antonio García y Bellido, «La latinización de Hispania», $A E \operatorname{spA}, 40,1967$, p. 24. Sobre la ciudad de Valencia como símbolo del proceso de adaptación, cf. Alfonso GarcíaGallo, 1978, cit. (n. 67), pp. 549-575. 
pretende representar fecundo y próspero a través del tiempo mítico de los orígenes. Tiempo de continua generación, cuando el linaje originario de los guerreros-pescadores asociados al monstruo, ocupaban aquel territorio en el que ahora se asientan los veteranos de Sertorio. En cuanto al resto del vaso, el conjunto de la imagen complementa y arropa al mito: la representación de la naturaleza no es aquí ajena al surgimiento milagroso ni tampoco es mero complemento ornamental. Es parte del thauma cósmico. Los animales de la tierra - el ager- abandonan su cubil y acuden presurosos al límite con el mar, el oppidum, que pueblan monstruosos guerreros míticos. Los cuadrúpedos y el gallo corren, vitales y fecundos, solidarios y llenos de curiosidad ante el prodigio. Cada ser aportará su cualidad, su virtud propia: el «carnassier» la fiereza, modelo del poderoso arraigado en la vieja tradición ibérica; las numerosas ubres cargadas de leche de la yegua podrán alimentar a los recién nacidos; el gallo anun- ciará el evento y cantará el nacimiento de las armas. Son presagio enviado por los dioses, símbolo de su asistencia en el nuevo orden de los siglos ${ }^{90}$. Lo humano, en gestación, en parte aún indistinto y mixto, comparte su nicho con las fieras ${ }^{91}$. De este modo se expresa el diálogo del linaje de los animales, el $g e$ nus animantum, con el genus hominum, el linaje de la historia. Pues con palabras del filósofo alemán Jürgen Habermas «la convivencia de los hombres en una ciudad sólo puede estar en orden si está estructurada al modo del cosmos» ${ }^{92}$.

90 Del mismo modo la cierva es presagio y asistencia en la historia de Sertorio. Cf. la recensión de Pere Bosch Gimpera, «Adolf Schulten, Sertorius», Revista de Occidente, ${ }^{\circ}{ }^{\circ}$ 41 , Noviembre de 1926 , p. 270 . Si el mito cuenta, como creemos, la fundación de un lugar, queda entonces establecido el orden y el tiempo nuevo en la naturaleza. Se inicia con ello el tiempo de la historia.

${ }_{91}$ Cf. M. Serres, 1994, cit. (n. 23), p. 209

92 Jürgen Habermas, 1975, cit. (n. 61), p. 184.

\section{ANEXo \\ EXCAVACIONES EN VALENCIA: CONTEXTO ARQUEOLÓGICO DEL VASO «EL CICLO DE LA VIDA»}

POR

\section{M. ${ }^{a}$ LUISA SERRANO MARCOS}

Los restos arqueológicos localizados en las excavaciones de la plaza de Cisneros de Valencia abarcan desde la fundación de la ciudad en el siglo II a.C. hasta nuestros días, conservándose restos de las primeras viviendas, que con algunos cambios, perduraron hasta el año 75 a.C. en que fueron destruidas debido a las guerras sertorianas que asolaron toda la ciudad de Valencia. Este nivel quedó reflejado en este punto de la urbe, donde se encuentra un estrato de tierra con carbones, cenizas, algunos restos óseos humanos, elementos de la panoplia militar, ajuares domésticos como piezas de telar y objetos de hueso trabajado, y abundante cerámica ibérica y romana. Destaca una pieza ibérica con una decoración excepcional, se trata de una tinaja en la que aparecen representadas figuras animales junto a tres figuras fantásticas, mitad humanas, mitad animales, portando elementos bélicos que componen una escena única.

\section{INTRODUCCIÓN}

Entre los meses de marzo y noviembre de 1998, se efectuaron las excavaciones arqueológicas en la plaza de Cisneros n. ${ }^{\circ} 6$ de Valencia. Estas se realizaron en extensión en todo el solar con un total de $3110 \mathrm{~m}^{3}$ excavados, llegando a alcanzar los cinco metros de profundidad y localizándose importantes hallazgos arqueológicos que van desde el siglo II a.C. al siglo $\mathrm{xx}$.

Esta zona se encontraba situada desde el s. II a.C. dentro de la ciudad, al nordeste, a escasos metros de la muralla. Los hallazgos más antiguos recuperados en la excavación datan de la fundación de la ciudad de Valentia por el cónsul romano Décimo Junio Bruto, acaecida en el 138 a.C. Los primeros habitantes, soldados licenciados, que se asentaron como colonos, levantaron para instalarse con sus familias viviendas tipo barracón que, con al- 


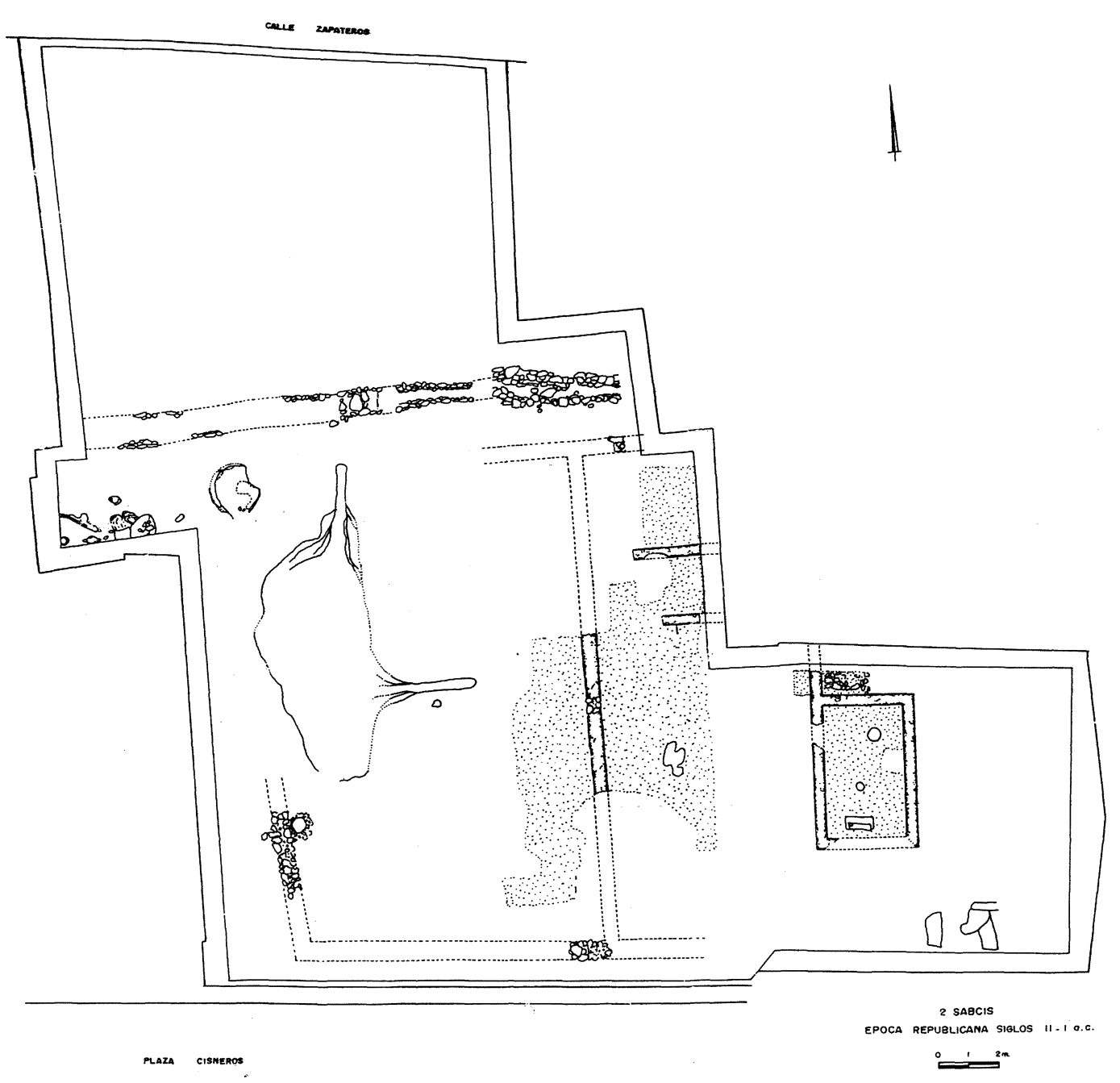

Fig. 1.-Plano general del solar. Época republicana, siglos II-I a.C.

gunas modificaciones, pervivieron hasta época sertoriana.

El final de este período viene marcado por la guerra civil entre el partido senatorial de Sula y el popular de Mario y Sertorio. Las fuentes escritas indican que la ciudad de Valentia se decantó por estos últimos, motivo que provocó la destrucción de la ciudad por Pompeyo en el año 75 a.C. Este episodio bélico, como hemos dicho, quedó constatado en la excavación con la presencia de un estrato de carbones y cenizas con fragmentos óseos humanos, elementos de la panoplia militar, piezas de hueso y cerámica ibérica y romana.

Tras algunos años de abandono, en torno al cambio de era y sobre el nivel de destrucción anteriormente descrito, se instalaron pequeños talleres artesanales entre los que destaca un obrador de alfarero.

Con el Alto imperio comienza una etapa flore- ciente en la vida urbana de la ciudad. Valencia en estos momentos cuenta con grandes edificios públicos distribuidos en torno al foro, situado en la actual plaza de la Almoina (QDA 4). También tiene edificios dedicados al esparcimiento como es el circo, que ocupa desde la actual plaza Nápoles y Sicilia hasta la calle de la Paz (Ribera, A. 1998). Está dotada de servicios de infraestructura, como el abastecimiento de agua a través de acueductos y la red de alcantarillado por medio de cloacas. Este esplendor ha sido constatado en esta zona de la ciudad, pasando a convertirse en un área mercantil situada a escasos metros del puerto fluvial.

En la excavación se han documentado dos calzadas paralelas en dirección este-oeste que distaban entre sí $24 \mathrm{~m}$. La calzada meridional, posiblemente de origen republicano, medía 7'80 m de ancho. A finales del siglo II o inicios del III d.C. se porticó y 
pavimentó con grandes losas de piedra, dotándola de los sistemas de infraestructura correspondientes: agua potable y alcantarillado.

Entre estas dos calles se situaban dos grandes edificios en uso desde el siglo I al III, uno de ellos con la planta casi completa, perteneciente a un $m a-$ cellum. Éste era un edificio cerrado de planta cuadrada, de $24 \times 24 \mathrm{~m}$, que disponía de patio central y al menos quince estancias destinadas a tiendas y zonas de almacenamiento. En el ala este pudo disponer de un segundo piso, como lo indica el hueco de escalera

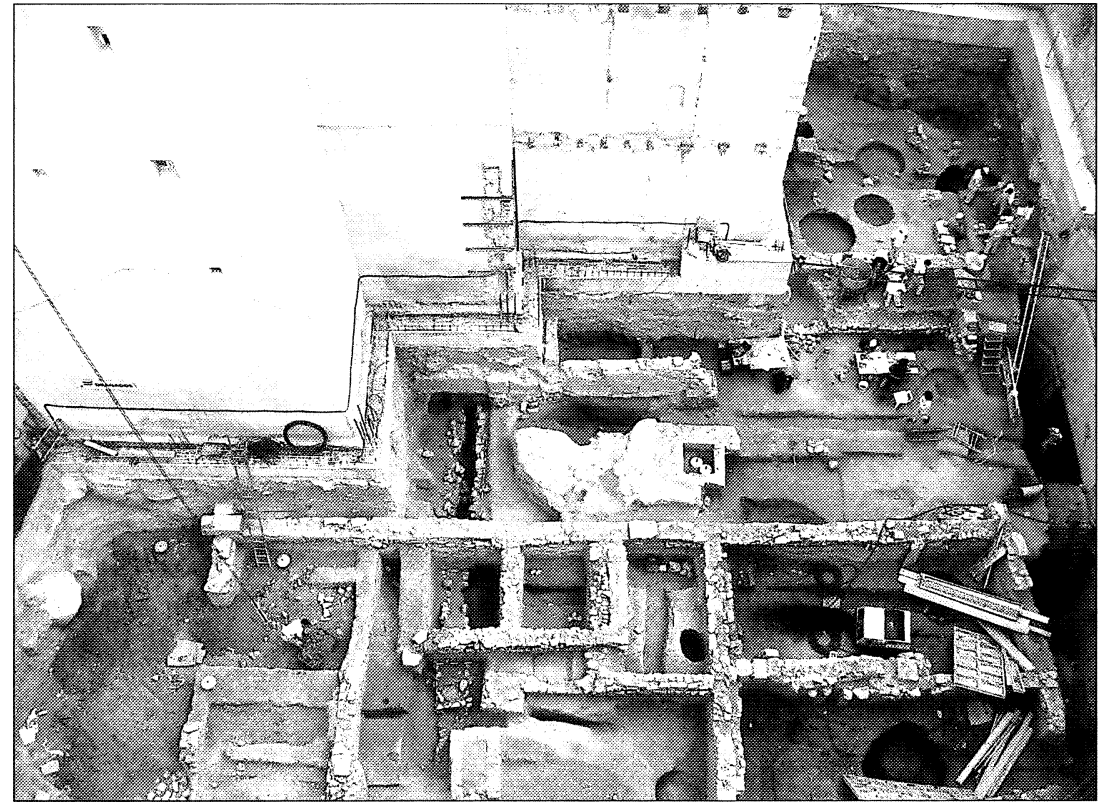

Fig. 2.-Vista general del solar, niveles romanos. documentado al norte del edificio.

En el Bajo imperio, los edificios anteriormente descritos dejan de funcionar, reaprovechándose algunos de sus muros para construir una casa taller artesanal (Albiach, R. y Soriano, R. 1991). De esta domus se localizaron siete estancias, en dos de ellas se hallaron sendos hornos de vidrio de planta circular y fábrica de ladrillos, junto a piezas vítreas tales como frascos, botellas, copas, vidrios de ventana y escoria de fundición.

En la segunda mitad del siglo IV esta zona se deshabitó, encontrándonos tan sólo algunas hogueras y un enterramiento infantil. Sin embargo el área este sigue estando habitada, persistiendo la edificación anterior que se remodeló y se amplió a expensas de la calzada porticada que de esta manera verá reducida su superficie.

A partir del siglo vi esta edificación también cae en desuso pasando a convertirse en área de almacenamiento, excavándose numerosos silos para cereales. Algunos de estos silos perduraron hasta el siglo vII, momento a partir del cual se utilizaron como basureros de los que se recuperó abundante material cerámico.

A partir de la segunda mitad del siglo xI, la zona queda englobada dentro de la nueva muralla construida por Abd al-Aziz en ese siglo, pasando a convertirse en toda una zona residencial donde se construyen siete viviendas articuladas en torno a una calle y a un atzucac. Estas viviendas fueron arrasadas por una fuerte riada ocurrida a finales del siglo XI.
Durante los siglos XII y XIII se reedifican las casas, aunque con técnicas constructivas diferentes. Tras la conquista cristiana de la ciudad por Jaime I en 1238, la zona quedó englobada en el barrio de Daroca, adscrita a la parroquia de San Lorenzo, donando el monarca sus viviendas a los individuos procedentes del Consejo de Aragón, que le ayudaron en la conquista. A partir de este momento el barrio sufre fuertes transformaciones relacionadas, sobre todo, con las nuevas creencias religiosas, construyéndose en el siglo XviII en este solar la casa procura de la Cartuja de Portaceli y el cementerio de la parroquia de San Lorenzo, en uso desde el siglo XIV al xx (Ruiz, E. y Serrano, M.L. 2000).

\section{LA FASE REPUBLICANA}

\section{LOS NIVELES DE FUNDACIÓN}

Las primeras evidencias de una cierta actividad humana esporádica se encuentran en un estrato natural de arcillas. Se trata de dos fosas excavadas en las arcillas, una de las cuales presentaba una fina capa de cal en superficie, estaba colmatada con arenas entre las que aparecían fragmentos desechados de una estructura de combustión, y en su base, y junto a una de las paredes, tenía piedras, de tamaño mediano y factura irregular dispuestas en una sola hilada, y una piedra de molino circular. 


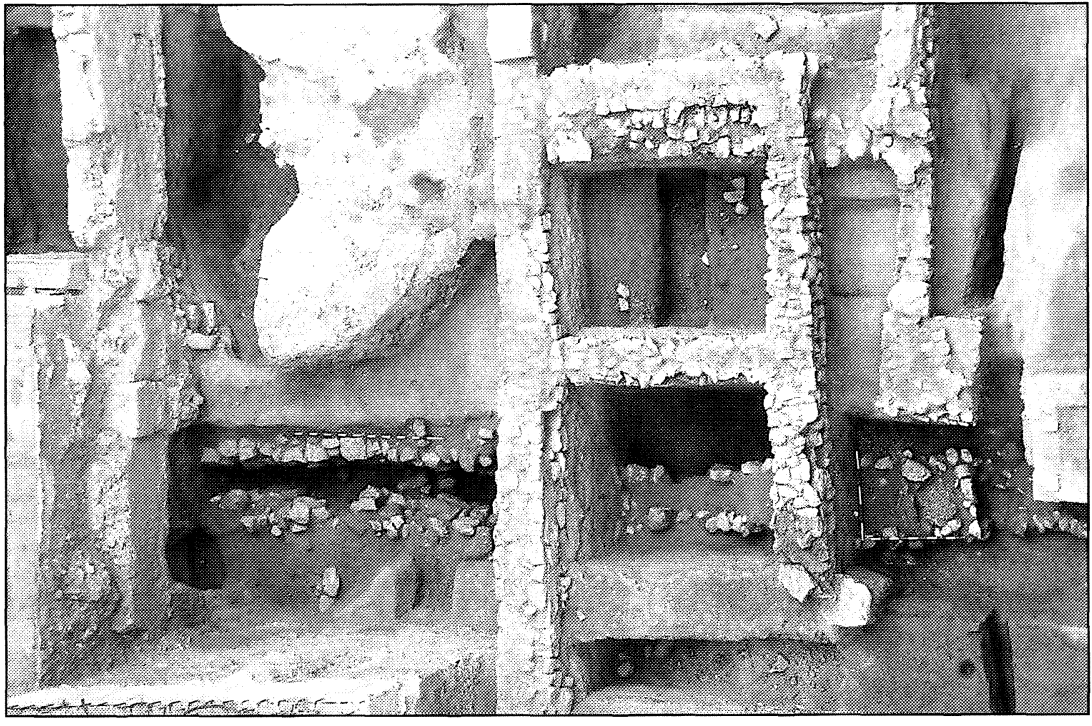

Fig. 3.-Cimiento perteneciente a posible empalizada. Nivel de fundación.

dose a su curvatura, se encajaron pequeños fragmentos cerámicos correspondientes a ánforas Dressel $1 \mathrm{~A}$, y, en menor cuantía, fragmentos de tinajilla ibérica con decoraciones geométricas. Este hogar estuvo en uso, como lo atestiguan las huellas del fuego perceptibles en el soporte cerámico de la estructura y el relleno de cenizas y carbones conservados en su interior.

Además se localizó otro fogón también de peculiares características. Se trata de un recipiente cerámico, un kalatho ibé-

Sobre este estrato arcilloso, que apenas ha evidenciado ocupación, aparece una deposición de arenas de carácter natural probablemente debida a una avenida del río Turia, vinculada a un asentamiento campamental, y sobre la cual se realizan las primeras construcciones provisionales que son de dos tipos, como veremos a continuación.

\section{De escasa entidad arquitectónica}

Corresponden a una serie de fosas que sirvieron de soporte a ánforas u otro tipo de contenedores, encontrándose en una de estas fosas un ánfora CC.NN casi completa (SanMartí, E. 1985). Otra fosa de este tipo destaca por su peculiar forma ahusada. Estaba rellena de tierra, caracoles, algunas gravas y fragmentos de cerámica ibérica (pátera, tinaja y kalatho), ánfora itálica y campaniense $\mathrm{A}$.

Junto a estas fosas se localizó una pequeña estructura rectangular, excavada en dicho estrato arenoso, que presentaba una oquedad circular de $43 \mathrm{~cm}$ de profundidad junto a la que aparecía un adobe, estructura que puede ser el resto de un poste de sustentación perteneciente a alguna construcción perecedera vinculada al primer asentamiento romano de la zona.

Otras evidencias de asentamiento humano la determinan los hogares domésticos, dos de ellos elaborados de modo peculiar. Para la construcción de uno de ellos se excavó directamente en la tierra una pequeña fosa de planta circular en la que, adaptán- rico, que debía estar fuera de uso como tal por encontrarse su borde roto, embutido simplemente en la tierra y que, en el momento de su descubrimiento, presentaba restos de carbones. Sobre el fogón estaba dispuesta una olla de tipología ibérica, tal y como debió quedar en el momento de su abandono. Como en el caso del hogar anterior, también éste presentaba huellas de fuego, formando un circulo de tierra quemada alrededor del kalatho cuyas paredes estaban calcinadas.

Otro tipo de estructuras constatadas de este primer momento, son zanjas rectangulares de largo recorrido excavadas en la tierra, que pudieron servir como conducciones de aguas residuales al confluir en pendiente a una gran fosa. Esta gran fosa pudo realizarse para la extracción de tierra utilizada en la construcción de los tapiales de las primeras viviendas de esta parte de la ciudad. Posteriormente, serviría de basurero, colmatándose con abundante material cerámico destacando piezas de cerámica campaniense A (formas 5, 25, 28, 36 de Lamboglia), campaniense B, etrusca (6 de Lamboglia) entre otras, tales como ánforas itálicas, cerámicas ibéricas, así como abundantes objetos de hueso trabajado (agujas de coser, husos y punzones) y monedas de bronce. Destaca la abundancia de grafitos en las piezas de cerámica campaniense, correspondientes a letras del alfabeto latino normalmente en grupos de tres, que aparecen sobre la pared, realizadas con una burda incisión y que correspondían a marcas de propiedad.

Otros pequeños basureros, realizados en estos primeros momentos pero de menor tamaño, se en- 
contraron rellenos con fragmentos de ánfora itálica e ibérica, cerámica común itálica, cerámica ibérica, fragmentos de campaniense A y restos de fauna.

\section{Estructuras construi- das}

Las primeras estructuras de hábitat de cierta entidad arquitectónica se localizaron al sudeste del solar, pudiendo corresponder a barracones de un campamento romano o a modestas estructuras de hábitat domésticas que

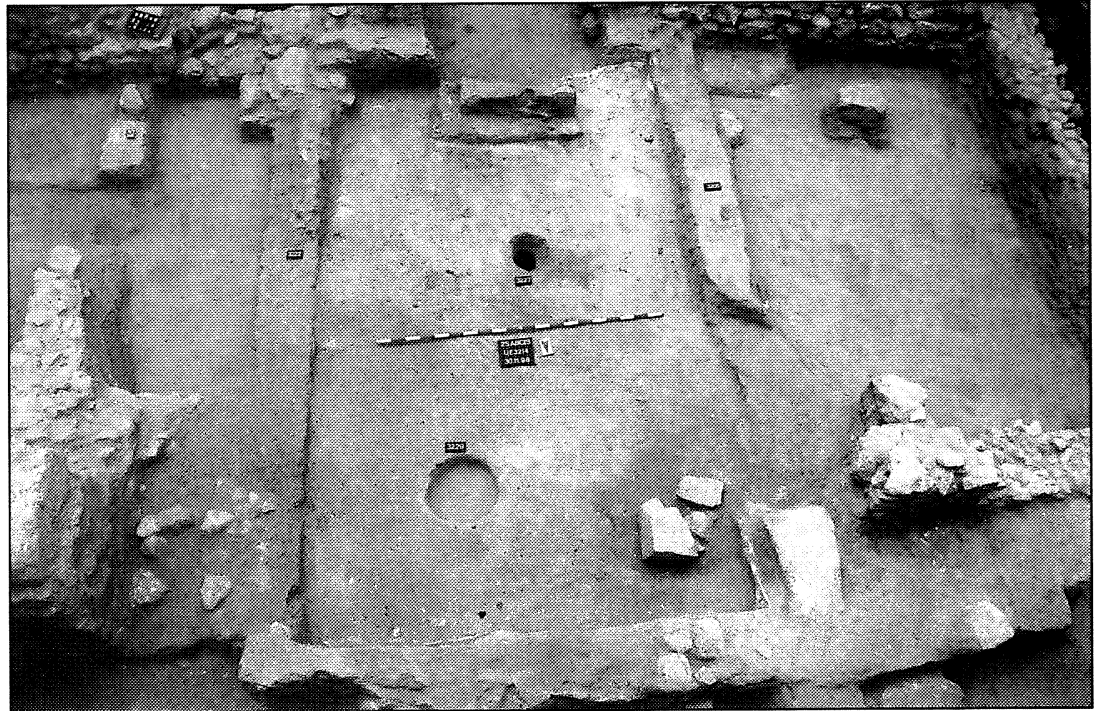

Fig. 4.-Estancia destinada a cocina. Nivel de fundación. formarían parte de un barrio periurbano.

De estas estructuras, se conservaban al este del solar tres estancias pertenecientes a una misma edificación de planta rectangular. La habitación mejor representada, cuyo uso sería el de una cocina, era de planta rectangular $(4,50 \times 2,75 \mathrm{~m})$ orientada nortesur y delimitada por cuatro muros de tapial de tierra, que servirían de zócalo a un alzado superior de adobes. Los muros presentaban en sus caras interiores un fino enlucido de cal y en las esquinas bloques de piedra y cantos a modo de refuerzo. El suelo era de tierra compactada con una fina capa de cal. En su interior se encontraba una fosa de planta circular que pudo servir como soporte de una vasija. Al sur y en posición centrada, se situaba un hogar u horno

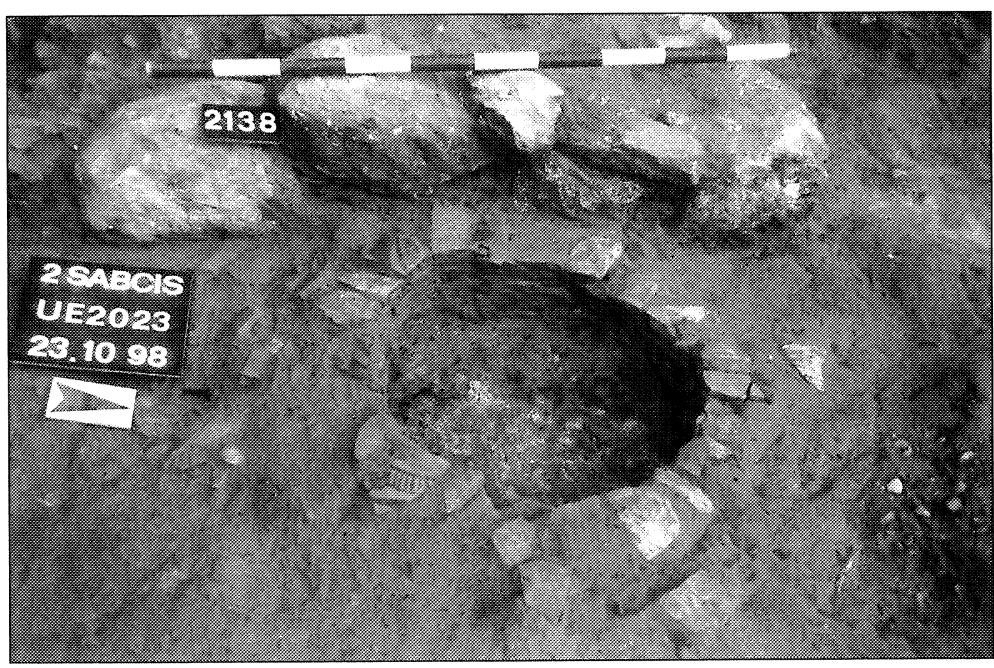

Fig. 5.-Hogar perteneciente al nivel de fundación. doméstico formado por una plataforma de adobes con la superficie rubefacta que conservaba parte del alzado de una bóveda, también de adobes, que se apoyaría en la cara norte de este muro.

Al norte de la cocina se situaban dos estancias divididas por un muro realizado de tapial de tierra y orientado norte-sur. Ambas habitaciones conservaban sus pavimentos realizados, uno de ellos, con una capa de mortero y lascas de piedra y el otro con piedras de tamaño mediano y pequeño dispuestas horizontalmente y trabadas con mortero de cal.

En el centro del solar se encontraron cuatro espacios más pertenecientes a una misma edificación, cuyos límites norte y sur venían marcados por muros de mampostería con piedras al exterior perfectamente careadas y escuadradas. Entre estos dos muros, otros dos, construidos con tapiales de tierra y orientados este-oeste, conformaban dos estancias al norte, cuyos pavimentos eran de tierra arcillosa compactada donde puntualmente se había conservado una lechada de cal y restos de tierra rubefacta, producto de hogueras. Uno de los muros se conservaba con un alzado de $70 \mathrm{~cm} \mathrm{y} \mathrm{su}$ cara norte enfoscada con mortero de cal.

Al sur de estas dos estancias, otro muro de tapial orientado norte-sur dividía el espacio en dos ambientes. La zona este presentó 


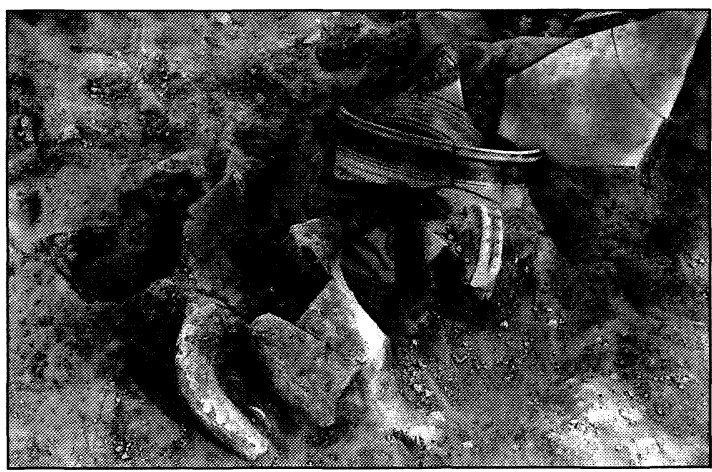

Fig. 6.-Detalle de una de las cerámicas del nivel de destrucción.

evidencias de actividad humana, documentándose un gran hogar. Al oeste de esta habitación se conservaba una amplia superficie perteneciente a un piso de tierra, probablemente a cielo abierto sin que en él se apreciara ningún tipo de actividad antrópica.

Estos primeros barracones o viviendas se encontraban delimitadas al norte por una construcción excepcional realizada en los primeros momentos de la fundacion de la ciudad (s. II a.C.), correspondiente a una estructura que atraviesa todo el solar de este a oeste y cuya interpretación plantea diversos problemas. Para su edificación se excavó una zanja de sección en cuña y en su interior, adosados a las paredes, se situaron dos muretes de piedras de tamaño mediano dispuestas de forma irregular y combinadas con cantos de río, trabadas con tierra arcillosa entre las que se recuperó un fragmento de ánfora itálica. Su interior se encontraba cubierto de tierra arcillosa y en algunos tramos por piedras y cantos.

El uso de esta construcción se presta a diversas interpretaciones. En un principio, sus características, la longitud de su trazado y la ausencia de hábitat al norte de ella nos indujeron a pensar en la posibilidad de que se tratara del límite construido del recinto fundacional. Esto es, que esta construcción perteneciera a un recinto de madera o empalizada cuya base o cimiento sería la estructura localizada por nosotros. Posteriormente se han planteado nuevas opciones tales como que se trate de una conducción realizada para drenar el terreno, aunque no parece haber evidencias claras de este uso.

En cualquier caso, lo conservado no es más que parte del alzado de esta construcción, lo cual hace aventurada cualquier hipótesis. La estructura apareció alterada y expoliada en todo su recorrido ya que sobre ella se halló una zanja rellenada con tierras limosas que cortaba el estrato arenoso de formación natural. Este hecho induce a pensar que la estructura tuvo un alzado considerable, indicio que apunta más a la hipótesis de un cimiento perteneciente al primitivo núcleo de la urbe en época fundacional que al de una canalización.

\section{El NIVEL DE DESTRUCCIÓN}

Estas primeras edificaciones se encontraban destruidas y cubiertas por un estrato de tierra con carbones, cenizas, material cerámico y militar y algunos restos óseos humanos, producto de las guerras sertorianas que asolaron la ciudad en el año 75 a.C.

De este nivel de destrucción e incendio se recuperaron materiales cerámicos fechados en el primer cuarto del siglo I a.C., tales como campaniense A, beoide (formas Lamb.1, 2, 5 y 8), ánforas itálicas (Dr.1B y 1C) y púnicas (Mañá C-2), paredes finas (formas II y III de Mayet), cerámica de cocina de procedencia itálica (cazuelas de borde bífido, ollas y tapaderas) y cerámica ibérica (tinajas, Kalatho, lebes de borde moldurado, páteras, pithoi Induratin, platos y vasos caliciformes). Además se encontraban piezas de telar (pondus y fusayolas), agujas, husos, punzones y horquillas de hueso, una fíbula de bronce y una veintena de monedas de bronce, sextantes ibéricos de Arse (Sagunto), quadrantes ibéricos de Arse (Sagunto), AS ibérico de Sekaisa (Segeda, Zaragoza), AS ibérico de Tamaniu (Valle del Ebro), AS ibérico de Saiti (Xàtiva), AS ibérico de Celsa (Velilla del Ebro, Zaragoza), un semis de Valentia y un AS de Roma.

El hallazgo más relevante en este nivel de la excavación es la localización de una pieza cerámica ibérica excepcional, que se encontraba arrojada, junto a otros materiales procedentes de ajuares domésticos y elementos militares, en el centro del solar, ocupando una superficie de no más de tres metros cuadrados y treinta centímetros de espesor. Esta pieza cerámica es una tinaja tipo A.1.2.2 del Tossal de Sant Miquel (Bonet, H. 1995). Su base de $13 \mathrm{~cm}$ de diámetro, presenta una ligera solera, el cuerpo es ovoide y el diámetro máximo, en la mitad superior del cuerpo es de $37 \mathrm{~cm}$. La boca, de 23 $\mathrm{cm}$, presenta un borde con labio exvasado y moldurado y su altura total es de $40 \mathrm{~cm}$. Tiene dos asas geminadas que parten bajo el cuello hasta la mitad superior de la panza. Su pasta es fina y depurada de color marrón claro-gris-marrón claro. Esta pieza, denominada vaso de «El Ciclo de la Vida» (Serrano, M.L., 1999), procede de un contexto bien fechado en el siglo i a.C. Su decoración, en color rojo vinoso, es excepcional e inédita hasta la fecha en las producciones ibéricas, mostrando en sus dos caras una escena con animales fantásticos que po- 
dría estar narrando un acontecimiento histórico vivido en Valencia.

Junto a ella se encontraba otra gran tinaja ibérica completa y decorada con motivos geométricos y vegetales, fragmentos de kalathos, lebes, olpes, pateras y abundante material cerámico romano completo entre el que destacan varias piezas completas de campanienses beoide (formas documentadas Lamb. 1, 2, 4, 8 y 10), un pyxide imitación de la forma Lamboglia 3 y un plato de barniz negro de imitación de Lamboglia 5, cerámica gris ampuritana, fragmentos de ánforas itálicas (Dr. 1B y 1C), una lucerna de la forma Dressel 2 con decoración en el mango, y fragmentos de cerámica de cocina de procedencia itálica, como cazuelas de borde bífido, ollas y tapaderas. También se recuperaron utensilios pertenecientes a la panoplia militar, una punta de espada de hierro, dos cuchillos de hierro y parte de un pectoral de hierro de un soldado. Finalmente, piezas de telar (fusayolas y pondus), una fíbula de bronce y agujas, husos, punzones y horquillas de hueso.

$\mathrm{Al}$ este del solar se encontró una fosa relacionada con la limpieza de esta fase de destrucción, cuyos rellenos datamos con posterioridad al episodio bélico de las guerras sertorianas.

Entre las tierras y cenizas que rellenaban esta fosa destacan los siguientes materiales: un proyectil de catapulta (esfera de piedra), un dardo de bronce, una fíbula, un AS ibérico de Ikalkusken (Cuenca) y algunos restos óseos humanos. Se recogieron abundantes restos de ánfora Dr. $1 \mathrm{~B}$ y $1 \mathrm{C}$ y campaniense beoide decorada con el motivo de la losange.

En la zona central del solar, sobre el estrato de la destrucción, aparecieron restos de un nivel de ocupación constituido por un estrato de carbones y cenizas asociado a numerosos orificios circulares practicados en el suelo con restos de carbón vegetal en su interior. Estos restos se interpretaron como una ocupación al aire libre, huellas de estacas colocadas para hacer numerosas hogueras. También se hallaron en el mismo nivel, cuatro estructuras de combustión excavadas directamente en la tierra, de planta rectangular con los extremos redondeados y en pendiente hacia la base llana, y con sus paredes calcinadas por haber estado en contacto directo con el fuego. En una de estas cubetas, al norte y centro, y junto a los lados largos, había dos oquedades circulares cuyas paredes también se veían endurecidas por efecto del fuego. No se conservaba el alzado real (tenía $25 \mathrm{~cm}$ de altura, $96 \mathrm{~cm}$ de longitud conservada y $27 \mathrm{~cm}$ de anchura), aparecía arrasado y cubierto por un estrato de tierra marrón compacta, de textura limoarenosa, con gravas, cal y carbones

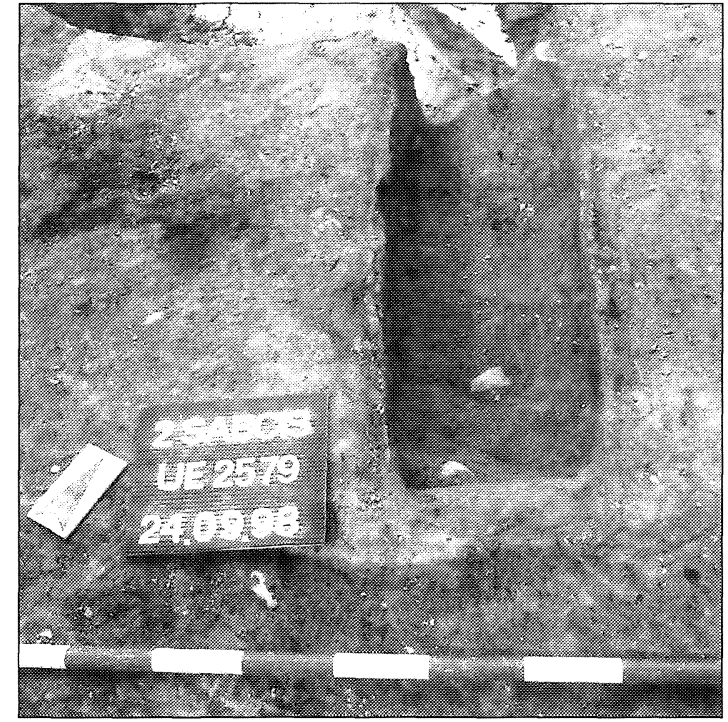

Fig. 7.-Cubeta de instalación metalúrgica.

en el que se recuperaron abundantes fragmentos de ánforas itálicas y cerámica ibérica, cerámica común y de cocina y fragmentos de campaniense beoide. Estos materiales dan fechas de la segunda mitad del siglo I a.C.- inicios del s. I d.C., de modo que la estructura de combustión se construyó y utilizó entre época sertoriana y estas fechas.

Las cubetas aparecieron exentas de cualquier otro elemento, interpretándose como hornos de simple factura cuya utilidad podría ser metalúrgica, sin poder confirmarse dado los pocos residuos aparecidos. En otros puntos de la ciudad, como en las excavaciones de la Almoina, también se documentaron cubetas parecidas que fueron interpretadas para fundición de armas (Ribera, A. 1998).

Tras las guerras sertorianas, los primeros indicios de nuevas construcciones datan de finales del siglo I a.C.-I d.C. En esta zona limítrofe de la ciudad se instaló un taller alfarero de la que se conservaban tres estancias con muros de mampostería y pavimentos de tierra arcillosa muy compactada. Su primera habitación, situada al sur, se encontraba delimitada por muros de mampostería y sillarejos, de aspecto sólido que tal vez sirvieron para aguantar algún tipo de cubierta, y su pavimento estaba realizado con arcillas rojas y tierra compactada. Dentro de ella se conservaba una balseta de planta rectangular construida con adobes que debió usarse para la decantación de arcillas y en cuyo interior aparecieron restos de arcilla y cerámica sin cocer. Junto a ella se encontraron elementos de sustentación consistentes en piedras ligeramente elevadas del suelo, dispuestas horizontalmente y alineadas de 
forma paralela a los muros este y oeste. La misma finalidad tuvo un agujero de poste que se calzó con varias piedras en forma de cuña.

El espacio central del taller debió de estar a cielo abierto, sin ningún tipo de cubierta, dada la actividad aquí desarrollada y las evidencias materiales. Se encontró un horno cerámico orientado de norte a sur de la habitación, semejante al recuperado en las excavaciones de la Almoina de Valencia (Ribera, A., 1998). Es de planta cuadrada, de aproximadamente dos metros de lado, con la cámara de combustión dividida en dos por un pilar enfrentado al praefurnium o boca del horno. Conservaba un alzado de aproximadamente $25 \mathrm{~cm}$ y las cenizas de la última cocción. Delante de su boca se pudo comprobar como, a lo largo de su existencia y funcionamiento, se efectuaron varias refacciones tendentes a su mejora. La última de las refacciones, con la que se eleva el piso, se efectuó con fragmentos de tégula y cerámica, concretamente trozos de ánfora, uno de ellos con un sello o estampilla en que se puede leer TRVfo.

El pavimento de este espacio central se acondiciona con tierra compactada y en él aparecen adobes dispuestos horizontalmente junto con un agujero de poste de planta circular. Sobre él destaca la aparición de abundantes vasos de paredes finas del mismo tipo que los encontrados dentro y delante del horno, cuya característica más notoria es la decoración con pequeños mamelones aplicados.

La zona norte de esta alfarería es más compleja de interpretar al encontrarse muy destruida por las estructuras de época imperial. Los materiales cerámicos asociados a estos pisos de tierra y arcilla son rojo pompeyano y tierra sigillata aretina.

$\mathrm{Al}$ este de esta alfarería se localizó un gran espacio posiblemente doméstico, delimitado por muros de mampostería revestidos en su interior con argamasa de cal. El suelo, de tierra compactada, presentaba zonas con huellas de rubefacción debido posiblemente a hogares domésticos. En esta estancia se documentó una estructura de planta circular formada por lajas de piedra hincadas verticalmente que debió servir de soporte de alguna vasija o contenedor. A este edificio se accedería por el sur del solar, donde se encontró un pavimento datable a partir del año 15 a.C./30 d.C. y que estaba construido con una capa de hormigón de cal asentado sobre un relleno de nivelación en los que se recuperaron varios fragmentos de TS Aretina de forma conspectus 18.1 datable entre el año 10 a.C-20 d.C.

Finalmente, al oeste del solar, junto al taller alfarero, se documentó un gran recinto muy mal con- servado. Se trata de una edificación de planta rectangular de la que se conservaban parte de dos estancias de 3'40 × 3 y 4' $50 \times 3^{\prime}, 40 \mathrm{~m}$, cuyos muros eran de mampostería con piedras de tamaño medio en la base y más pequeñas en su alzado.

\section{BIBLIOGRAFÍA}

Albiach, R. y SoRiano, R. (1991): «Estudio de una "Domus" romana de Valentia y de los niveles que la amortizan». P.L.A.V. 24. 75-95. Valencia.

Marín, C., Piá, J. y Rosello, M. (1999): «El foro romano de Valentia». Quaderns de Difusió Arqueològica, 4. Ayuntamiento de Valencia. Valencia.

Ribera i Lacomba, A. y Calvo, M. (1995): «La primera evidencia arqueológica de la destrucción de Valentia por Pompeyo». Journal of Roman Archaelogy. Ann. Arbour.

Ribera i Lacomba, A. (1998): «La fundació de Valencia. La ciutat a l'època romano republicana (SS. II-I a. C.)». Estudis Universitaris 71, Institució Alfons el Magnanim. Valencia.

Ribera i LACOMBA, A. (1998): The discovery of a monumental circus at Valentia». Hispania Tarraconensis. JRA, 11. Portsmouth.

SANMARTí, E. (1985): «Sobre un nuevo tipo de ánfora de época republicana, de origen presumiblemente hispánico». Ceramiques Gregues i Hel.lenistiques a la península ibérica, M.E. VII, 133-141. Barcelona.

Serrano Marcos, M. ${ }^{a}$ L. (1999): «Excavaciones en Valencia: 22 Siglos de Historia». Revista de Arqueología, 221, 26-35.

Serrano Marcos, M. ${ }^{a}$ L. (2000): «El Vaso del Ciclo de la Vida». Revista de Arqueología, 234, 22-29.

Serrano Marcos, M. ${ }^{a}$ L. (2000): «Hallazgos Arqueológicos de la Plaza de Cisneros n. ${ }^{\circ} 6$ de Valencia». Catalogo de la exposición L' Arqueología fa Ciutat: Les Excavacions de la Plaça de Cisneros, 9-22. Valencia.

Serrano Marcos, M. a'L. y Martínez García, R. (2000): «El Vaso de «El Ciclo de la Vida» (Estudio Preliminar). Catalogo de la exposición $L$, Arqueología fa Ciutat: Les Excavacions de la Plaça de Cisneros, Valencia, 27-30.

Ruiz Val, E. y Serrano Marcos, M. ${ }^{2} L$. (2000): «La iglesia y el cementerio parroquial de San Lorenzo». Catalogo de la exposición L'Arqueología fa Ciutat: Les Excavacions de la Plaça de Cisneros. Valencia, 49-52. 